\title{
4. STRATIGRAPHIC AND TECTONIC EVOLUTION OF BROKEN RIDGE FROM SEISMIC STRATIGRAPHY AND LEG 121 DRILLING ${ }^{1}$
}

\author{
Neal W. Driscoll, ${ }^{2,3}$ Garry D. Karner, ${ }^{2}$ Jeffrey K. Weissel, ${ }^{2}$ and the Shipboard Scientific Party ${ }^{4}$
}

\begin{abstract}
Vertical motions of the lithosphere are preserved in the stratigraphic record of sedimentary basins. It is generally accepted that extension results in major vertical motions of the lithosphere that, in turn, lead to rift basin subsidence and rift flank uplift. However, the history of the timing of the extension process sometimes is poorly understood, primarily because the preand syn-rift stratigraphy is either removed by erosion or deeply buried by subsequent post-rift sedimentation. Therefore, it is often difficult to determine the evolution of the entire rifting process from the study of terrestrial rift basins. The rifting of oceanic lithosphere offers a unique tectonic setting because of the greater potential for sediment preservation within the marine environment. Broken Ridge, a rifted and relatively shallowwater platform in the southeastern Indian Ocean (Fig. 1), is an ideal locale for using the preserved stratigraphy to reconstruct the tectonic events responsible for its present structure. The purpose of this paper is to reconstruct the stratigraphic and tectonic evolution of Broken Ridge from the seismic stratigraphic, drilling, and underway geophysics data.
\end{abstract}

Approximately $4400 \mathrm{~km}$ of high-resolution water gun seismicreflection data was collected aboard Robert D. Conrad Cruise 2708 (RC2708) during the site survey for Ocean Drilling Program (ODP) Leg 121 (Fig. 2). In addition, over 50 sonobuoys were deployed to ascertain the velocity structure of the sedimentary section in the study region. These data were analyzed in conjunction with existing seismic-reflection profiles to investigate the nature of the rifting process by identifying the pre-, syn-, and post-rift stratigraphy. This approach is possible because predictable stratigraphic relationships should develop in response to relative sea-level changes (Vail et al., 1980; Vail, 1987) that are, in turn, associated with the rifting and uplift of Broken Ridge. The unconformity-bounded stratal packages that developed on Broken Ridge record the interaction of tectonic uplift, thermal subsidence, sediment supply, and eustatic sealevel variations (Pitman, 1978; Vail et al., 1984).

\section{GEOLOGICAL SETTING OF THE SOUTHEAST INDIAN OCEAN}

Broken Ridge and Kerguelen-Heard Plateau in the southeast Indian Ocean appear to be conjugate rifted margins of a preexisting shallow-water platform (Mutter and Cande, 1983). Dredged basalts, mostly tholeiites, from Broken Ridge/Kerguelen-Heard Plateau suggest that it formed as a consequence of excessive volcanism at or near a spreading center prior to the Santonian (Leclaire et al., 1987; RC2708 unpubl. data; dredge RC2708-10; Leg 120 Shipboard Scientific Party, 1988). Cenomanian-Turonian calcareous sediments cored from the southern

\footnotetext{
${ }^{1}$ Peirce, J., Weissel, J., et al., 1989. Proc. ODP, Init. Repts., 121: College Station, TX (Ocean Drilling Program).

2 Lamont-Doherty Geological Observatory, Palisades, NY 10964.

3 Also at Department of Geological Sciences, Columbia University, Palisades, NY 10964.

${ }^{4}$ Shipboard Scientific Party is as given in the list of Participants preceding the contents.
}

Kerguelen Plateau (piston core EL5407; Quilty, 1973) overlie basaltic basement, which further constrains the cessation of the volcanic platform-building episode. Morgan (1981) postulated a hot-spot origin for the excessive volcanism that resulted in the formation of the Broken Ridge/Kerguelen-Heard and Naturaliste Plateau. The trend of this hot-spot-related bathymetry results from the initial northwest movement of India, with respect to Australia and Antarctica, beginning in the Neocomian at about the time of anomaly M11 ( 127 Ma; Markl, 1974). The hot spot subsequently engendered the formation of Ninetyeast Ridge, thereby documenting the northward movement of India with respect to Antarctica, beginning in the Late Cretaceous (anomaly 34). The Rajmahal and Bunbury continental flood basalts on the trailing edges of the Indian and Australian continents, respectively, are also consistent with the hot-spot model for the origin of the Broken Ridge/Kerguelen-Heard platform (Coleman et al., 1982; Mahoney et al., 1983).

\section{GEOLOGICAL SETTING OF BROKEN RIDGE}

Broken Ridge is an essentially continuous west-northwesttrending oceanic plateau, more than $1000 \mathrm{~km}$ in length and approximately $100 \mathrm{~km}$ wide where it is shallower than $2000 \mathrm{~m}$ (Fig. 1). The ridge is markedly asymmetric in cross section, gently dipping $\left(<1^{\circ}-2^{\circ}\right)$ toward the north, in contrast to the more steeply dipping south-facing escarpment $\left(>10^{\circ}\right)$.

The development of a major angular unconformity on Broken Ridge attests to its uplift and subsequent erosion. During uplift, pre-existing strata were gently tilted toward the north. Thermal subsidence across the entire Broken Ridge region led to the eventual resubmergence of the subaerially exposed parts, as evidenced by middle to late Eocene sand and gravel overlying the angular unconformity at Deep Sea Drilling Project (DSDP) Site 255 (Davies, Luyendyk, et al., 1974). The age of the oldest identifiable seafloor-spreading magnetic anomaly between Broken Ridge and the Kerguelen-Heard Plateau is approximately middle to late Eocene (anomaly 18, 42; Mutter and Cande, 1983; Munschy and Schlich, 1987), which suggests that the middle to late Eocene deposits are post-rift.

Results from DSDP Site 255, which is just above the southfacing scarp of Broken Ridge (Fig. 3A), indicate a 40-m.y. hiatus between the dipping limestones and cherts (Santonian age, 84-87 Ma) and the horizontal, lagoonal sands and gravels (middle to late Eocene age, $\sim 42 \mathrm{Ma}$; Davies, Luyendyk, et al., 1974) (Table 1). Recently acquired seismic-reflection data and $3.5-\mathrm{kHz}$ precision depth recorder (PDR) data indicate that Site 255 is within a small basin formed between the main southern escarpment of Broken Ridge and a normally faulted, downdropped (rider) block (Figs. 3A and 3B).

A relatively strong reflector at approximately $0.062 \mathrm{~s}$ twoway traveltime (TWT) below seafloor $(\sim 50 \mathrm{~m}$ below seafloor [mbsf]; Figs. 3A and 3B) within this small basin appears to correlate with middle Eocene gravels (upper part of Unit II, Site 255). However, no internal reflectors are observed on the main part of Broken Ridge. The sands and gravels may occur at a depth greater than the penetration capability of the $3.5-\mathrm{kHz}$ PDR (approximately 75-100 m; Fig. 3A). 


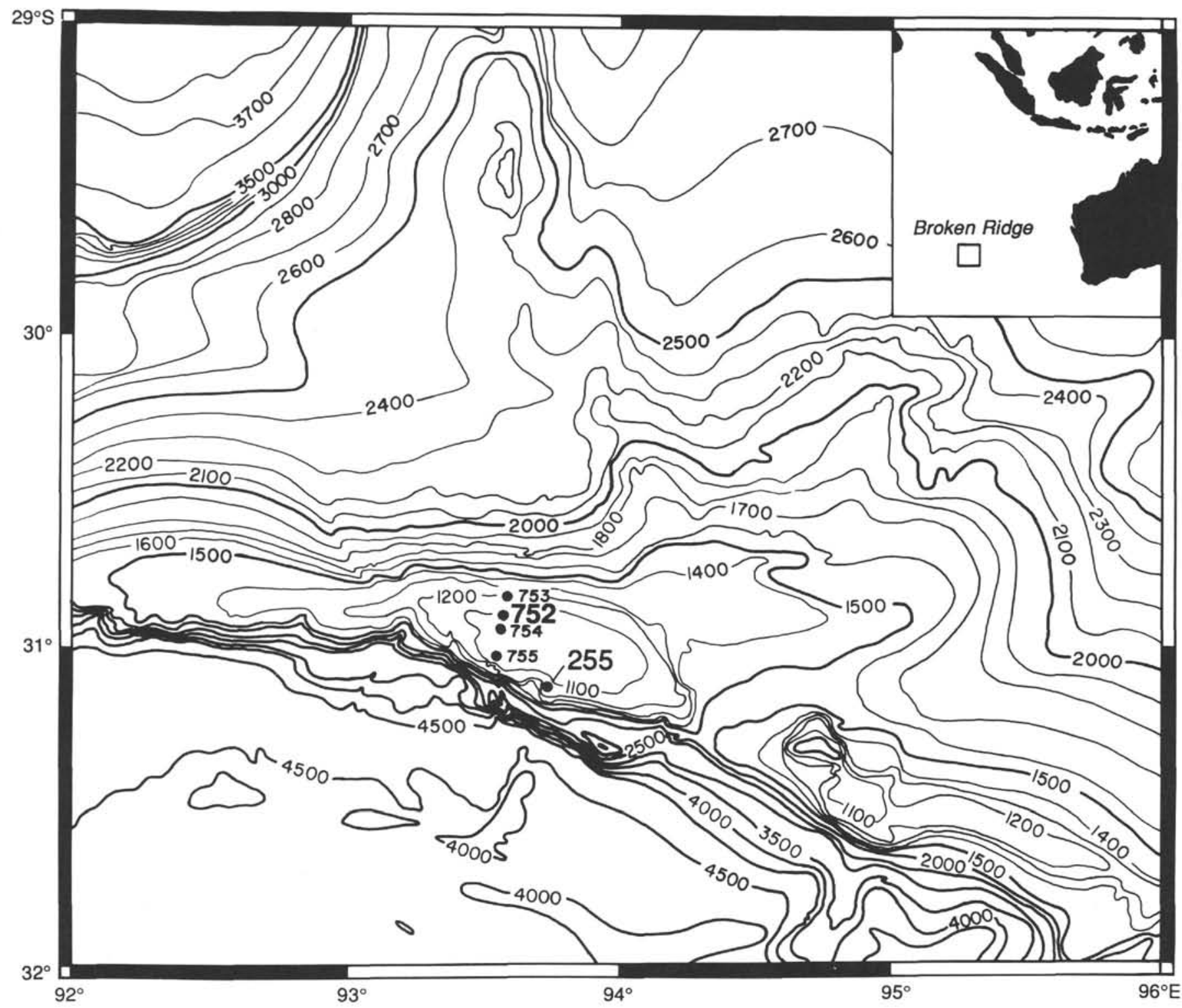

Figure 1. Bathymetry of Broken Ridge, from precision depth recorder data. DSDP Site 255 and ODP Sites 752 through 755 are shown. Contour inter$\mathrm{val}($ corrected $)=100 \mathrm{~m}$ except toward the south, where contours are omitted for clarity.

The lowermost unit sampled at Site 255 consists of dipping and truncated Santonian gray fossiliferous biomicritic limestones interspersed with chert stringers. This unit can be correlated across Broken Ridge using the water gun seismic data (Fig. 3B).

\section{METHODOLOGY}

A detailed study of the 12- and 3.5-kHz PDR records from Broken Ridge and the surrounding region $\left(92^{\circ}-96^{\circ} \mathrm{E}, 29^{\circ}-32^{\circ} \mathrm{S}\right.$; Fig. 1) generated a high-resolution bathymetric map. Dual 80 -in. ${ }^{3}$ water guns were used as a sound source for the RC2708 seismic survey on Broken Ridge. The spacing of the strike and dip lines facilitated mapping the seismic sequences (approximately $20 \mathrm{~km}$; Fig. 2). The seismic processing parameters were chosen to preserve the true amplitude variations in the seismic profiles (i.e., in both depth and distance). The technique of sequence analysis (Vail, 1987) was used to interpret the seismic stratigraphy of Broken Ridge and allowed the identification of five major seismic stratigraphic sequences (Figs. 4 through 6). Isopach and structural contour maps were generated to analyze the lateral and downslope variations in both sediment thickness and the pre-existing depositional surfaces. The velocity information used to create these isopach and structure contour maps was determined from sonobuoy data (Figs. 7 and 8 and Table 2). The ODP Leg 121 drilling data allowed correlation of the lithostratigraphy with the seismic stratigraphy (see "Seismic Stratigraphy" sections of "Site 752" through "Site 755" chapters; this volume) and also allowed recognition of the depositional paleodepths (Fig. 9).

\section{SEISMIC STRATIGRAPHIC SEQUENCES AND DRILLING RESULTS}

Five major seismic stratigraphic sequences have been identified on Broken Ridge (Figs. 4 through 6), according to the Vail (1987) technique of sequence stratigraphy.

\section{Dipping and Truncated Limestone and Chert Sequence}

The limestone, chert, chalk, and tuff sequence at the crest of Broken Ridge dips uniformly toward the north (approximately $2^{\circ}$ ) and appears to be roughly concordant with the underlying reflectors. The average thickness of this sequence is approximately $670 \mathrm{~m}$ above the high-amplitude reflector that outcrops on the ridge (Table 2; "Physical Properties" section, "Site 755" 


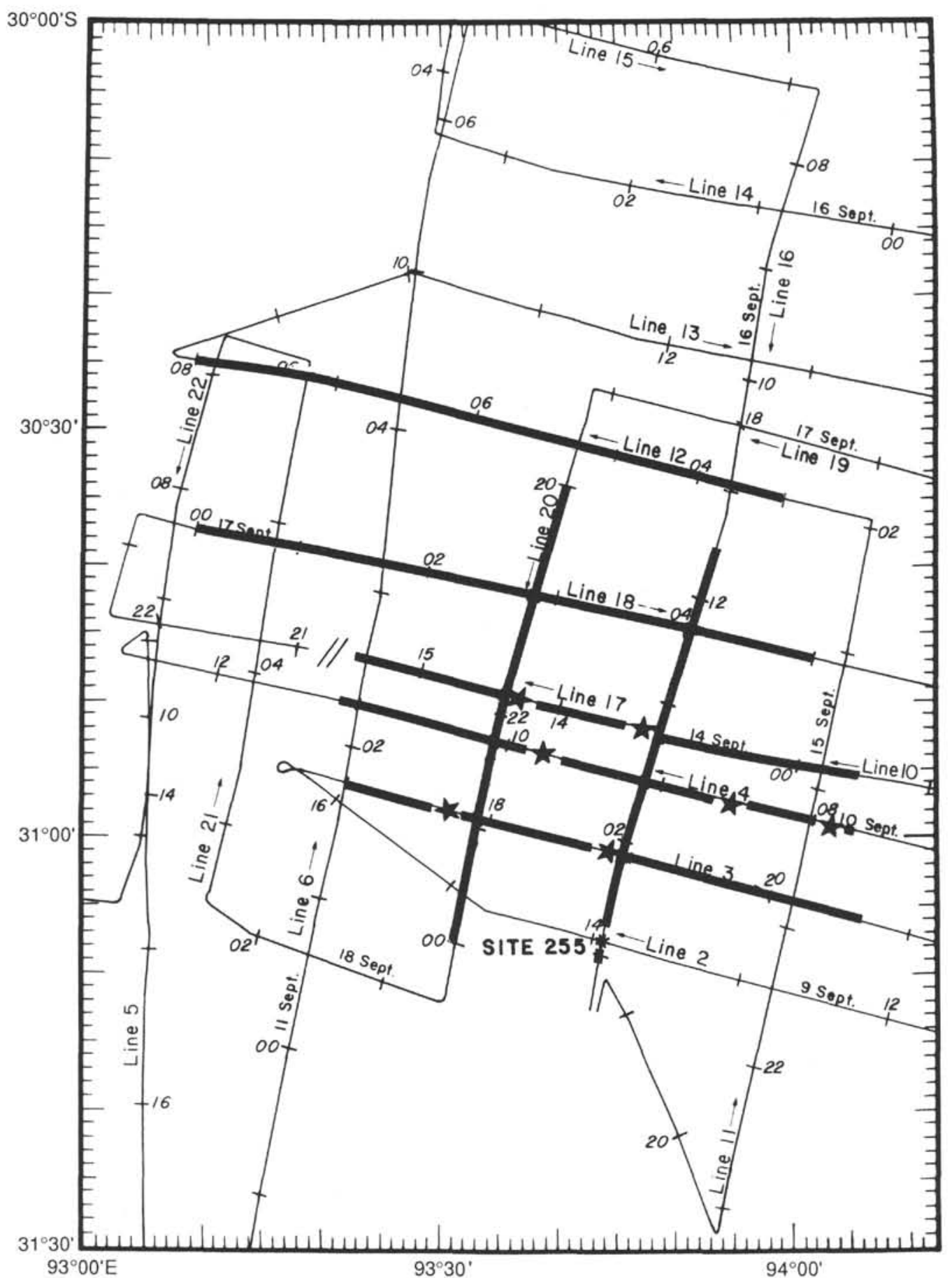

Figure 2. RC2708 ship's track location map for the Leg 121 study region. Heavy lines denote seismic figures discussed in the text; stars indicate sonobuoy locations along these lines.

chapter). The acoustic character of this sequence is discontinuous, with a wide range of lateral amplitude variations that could be the result of diagenetic horizons (Figs. 3B and 4).

Sampling of the oldest sedimentary section from Broken Ridge at ODP Site 755 revealed that the base of this seismic sequence consists of Turonian through upper Santonian tuffs, with varying amounts of glauconite and micrite (see "Lithostratigraphy and Sedimentology" section, "Site 755 " chapter). Traces of glauconite occur throughout the sequence, and glauconite is an important sedimentary component $(-5 \%-40 \%)$ in Cores 121 $755 \mathrm{~A}-13 \mathrm{R}$ to $121-755 \mathrm{~A}-18 \mathrm{R}$, from where it diminishes in abun- dance upsection. The micrite content increases upsection, and intervals of ashy limestone, interbedded within the tuffs, occur in Core 121-755A-6R and 121-755A-7R.

Benthic foraminifer data indicate upper bathyal to outer neritic paleodepths for this sequence (approximately $400 \mathrm{~m}$; Fig. 9). Because the total depth ranges are not well constrained for Site 755 , no terminations are indicated for the paleodepth ranges (Fig. 9).

The sonobuoy data reveal a prominent velocity discontinuity that approximately coincides with the boundary between the dipping and truncated limestone, chalk, chert, and tuff se- 
A

$\mathrm{N}$

RC2708 line 10

S
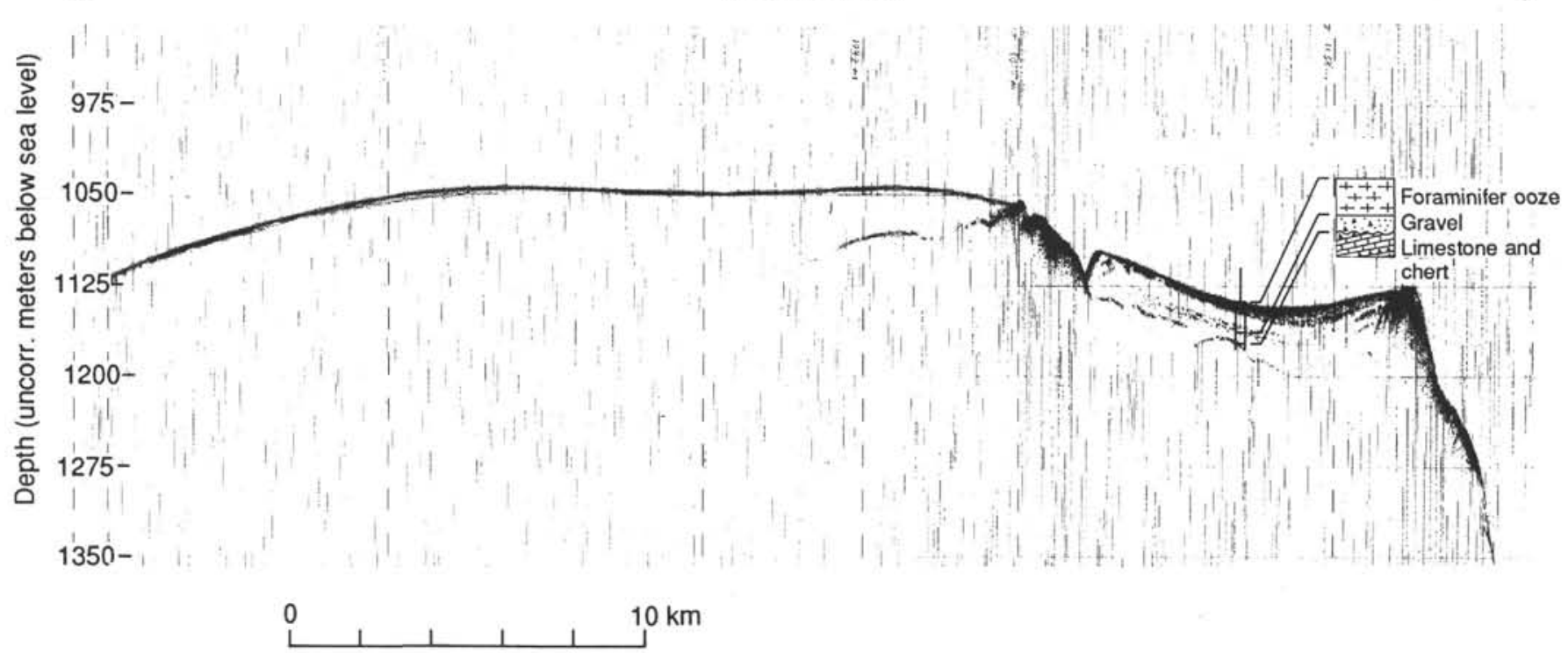

B
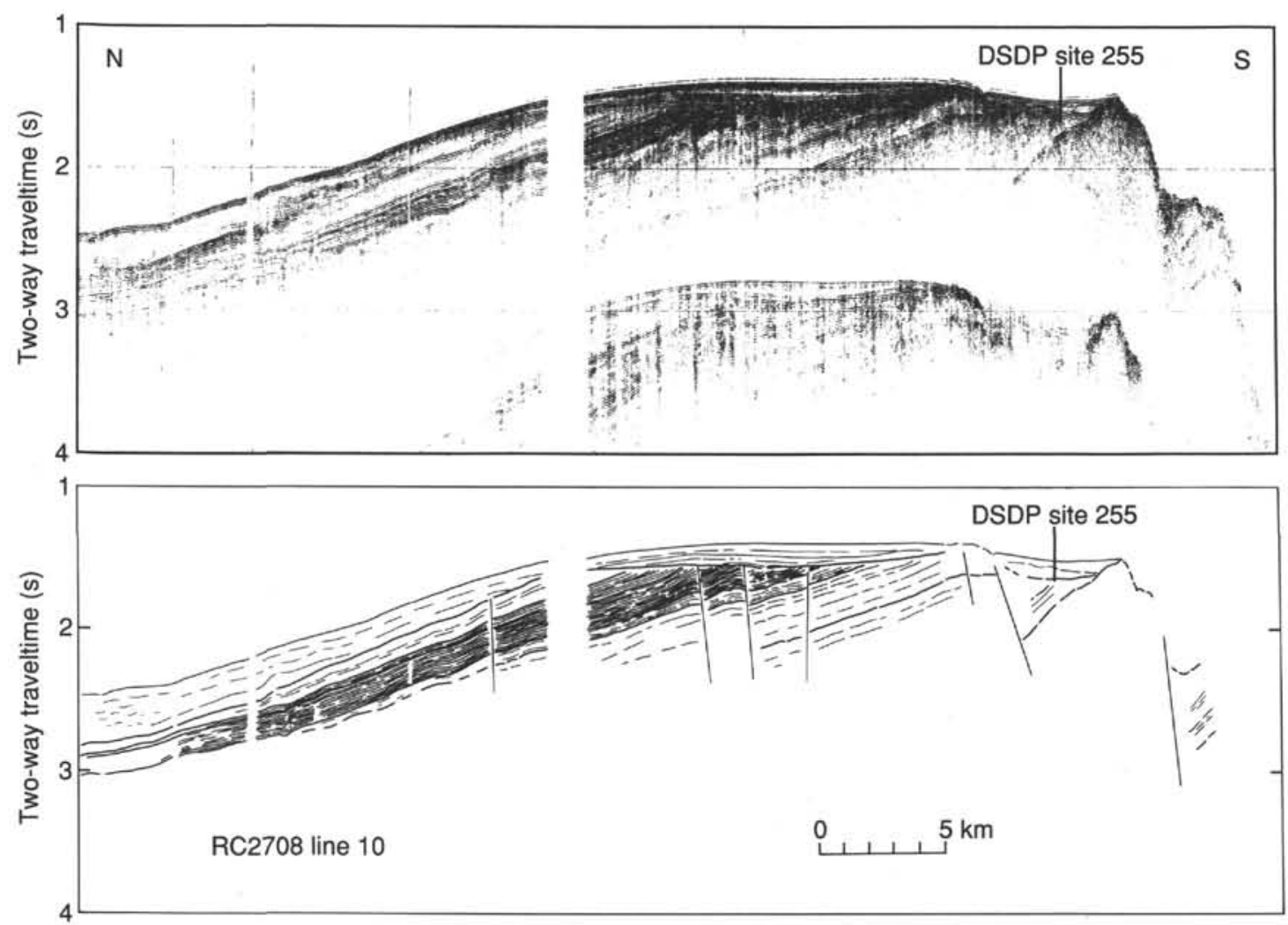

Figure 3. A. The 3.5-kHz PDR record collected over DSDP Site 255, correlating the sampled lithology at the site with the resulting acoustic character. B. The corresponding single-channel seismic line across Site 255 , which is within a small rider block basin perched on the southern escarpment of Broken Ridge. 
Table 1. Drilling results from DSDP Site 255 (Davies, Luyendyk, et al., 1974).

\begin{tabular}{|c|c|c|}
\hline Lithology & $\begin{array}{l}\text { Sedimentation } \\
\text { rate } \\
(\mathrm{m} / \mathrm{m} . \mathrm{y} .)\end{array}$ & $\begin{array}{l}\text { Acoustic } \\
\text { velocity } \\
(\mathrm{km} / \mathrm{s})\end{array}$ \\
\hline $\begin{array}{l}\text { Unit } 1 \text { ( } 0-55 \text { mbsf): Holocene to lower Miocene oozes } \\
\text { (silty/sand grain size). The lowest core recovered } \\
\text { from this unit contains some glauconite, traces of } \\
\text { zeolites, and ferruginous streaks. }\end{array}$ & $\sim 2.4$ & \\
\hline $\begin{array}{l}\text { Unit II (55-75 mbsf): lower Miocene to middle Eocene } \\
\text { sediment. Part I is a coarse gravel of reworked } \\
\text { limestone and chert fragments that overlies the yel- } \\
\text { low calcareous chalk of Part II. }\end{array}$ & & \\
\hline $\begin{array}{l}\text { Unit III (75-108.5 mbsf): Santonian gray fossiliferous } \\
\text { biomicritic limestones overlain by and containing } \\
\text { chert layers. Recovery of this unit was limited. }\end{array}$ & $\geq 6.7$ & $\begin{array}{l}\text { a Limestone: } 2.9 \\
{ }^{\mathrm{b}} \text { Chert: } 5.7\end{array}$ \\
\hline
\end{tabular}

a Mean velocity from three samples.

${ }^{b}$ From one sample.

quence and the prograding downlapping sequence (Figs. 7 and 8 and Table 2). The velocity jumps approximately 2.2 to $4.5 \mathrm{~km} / \mathrm{s}$ in less than $200 \mathrm{~ms}$ TWT between the respective layers (Fig. 7). Sonobuoy velocity solutions from strike lines (Fig. 8) are projected onto the dip line (seismic line 20), correcting for changes in water depth. The ODP downhole and laboratory-derived velocity data are in good agreement with the sonobuoy results, except for the dipping and truncated limestone, chalk, chert, and tuff sequence. The laboratory-measured average compressionalwave velocity for this sequence is $2.85 \mathrm{~km} / \mathrm{s}$, which is significantly lower than those derived from the sonobuoy data. These low-velocity zones are detected in the laboratory compressionalwave measurements but are not apparent in the sonobuoy data because no seismic energy is refracted upward from the low-velocity layers. Several high-velocity intervals (i.e., approximately $4.1 \mathrm{~km} / \mathrm{s}$ ) are interspersed within the low-velocity zones.

The contrast in velocity between the truncated limestone, chalk, chert, and tuff sequence and the prograding downlapping sequence may be the result of different depositional environments and/or different degrees of sediment compaction and lithification. RC2708 sonobuoy velocity results are consistent with previously determined velocity solutions from the Eltanin 48 sonobuoys deployed on the northern slope of Broken Ridge (Lamont-Doherty Geological Observatory Sonobuoy Data Bank, unpubl. data). Sonobuoy velocity data collected from the Kerguelen-Heard Plateau also show this pronounced velocity gradient from approximately 2 to $4.5 \mathrm{~km} / \mathrm{s}$ (Munschy and Schlich, 1987; Houtz et al., 1977).

\section{Prograding Downlapping Wedge}

Sediment thicknesses for the prograding downlapping wedge are greatest near the northern edge of the present Broken Ridge platform and thin progressively northward away from the ridge. The depocenter located toward the eastern segment of the study area is shown by the $700-\mathrm{m}$ contour in Figure 10A. An apparent depositional lobe extends to the northeast, away from the main depocenter. Its spatial configuration, however, appears to be structurally controlled by pre-existing topography, instead of being a depositional feature (Fig. 10B). A spoon-shaped normal fault occurs along the eastern part of the ridge (Figs. 10A and 10B).

An increase in the thickness of the prograding downlapping wedge occurs at depths of $2900-3200 \mathrm{~m}$ within the western part of the study region. The seismic profiles indicate that aggradation was dominant on the western segment of the ridge, thus increasing the pre-existing slope, whereas on the eastern section of the ridge progradation dominated and thus diminished the preexisting slope. The subtle difference in slope gradient along the ridge might have become sufficient to preclude further accumulation on the western part (Fig. 11B). The entire northern slope of the shallow-water plateau has been significantly modified by the prograding downlapping sequence (Figs. 10B and 11B).

The prograding downlapping wedge consists of three distinct acoustic units: (1) a lower weakly laminated unit that has highamplitude reflectors where it onlaps the pre-existing dipping strata, (2) a middle highly reflective unit, and (3) an upper finely laminated unit that is almost acoustically transparent (Figs. 4A and $4 \mathrm{~B}$ ). This abrupt change in acoustic character within the northward-dipping downlapping sequence, specifically the middle highly reflective unit, suggest a change in the mode of deposition and/or sediment composition.

The weakly laminated unit onlaps and downlaps the pre-existing dipping strata and modifies the northern slope of Broken Ridge. The change in paleoslope between the pre-existing dipping strata and the top of the weakly laminated downlapping unit is illustrated in RC2708 line 20 (Figs. 4A and 4B). The lower weakly laminated unit also has a subtle change in dip. A gentle northward dip occurs where the weakly laminated unit onlaps the pre-existing dipping strata, and the dip increases farther north. The roll-over point identifies the position of this small change in dip (Fig. 4B). The distal shift in the roll-over point suggests that the downlapping wedge was prograding into deeper water (Vail, 1987; pers. comm., 1988).

Downslope variations in the acoustic character of the middle highly reflective unit are readily apparent in seismic-reflection profiles (RC2708 lines 10 and 20, Figs. 3B and 4A, respectively). The high-amplitude acoustic character of this unit is indicative of high acoustic impedance contrasts, and the downlapping terminations are clustered in close proximity to the crest of Broken Ridge (Fig. 4A).

The upper finely laminated unit at the top of the prograding downlapping wedge varies laterally in thickness along the ridge. RC2708 seismic-reflection line 18, a strike line, clearly shows this lateral variation along the northern slope of the ridge, where the finely laminated unit thins toward the west (Fig. 5). Farther down the slope, RC2708 seismic line 12 illustrates a finely laminated lens of sediment at the top of the prograding downlapping wedge that thickens toward the western part of the seismic line (Fig. 6) and appears to be the stratigraphic equivalent of the finely laminated unit upslope (Figs. $4 \mathrm{~A}$ and 6 ). This inverse relationship of upslope/downslope sediment thicknesses implies that sediment bypassing occurred on the upper slope in the western region of the ridge, with upper slope deposition toward the east.

ODP Sites 752 through 754 all sampled the prograding downlapping sequence below the angular unconformity (Fig. 4A). Site 753 is along the northern margin of Broken Ridge, approximately $25 \mathrm{~km}$ north of the prominent southern scarp (Fig. 4; see "Seismic Stratigraphy" section, "Site 753" chapter). The youngest lithology below the prominent angular unconformity was sampled at Site 753, with the recovery of approximately $20 \mathrm{~m}$ of middle Eocene ( 45-50 Ma) nannofossil chalks with varying amounts of foraminifers.

Site 752 is approximately $10 \mathrm{~km}$ south of Site 753 (Fig. 4A). A 320-m section of dominantly lower Eocene to middle or upper Maestrichtian nannofossil calcareous chalks was recovered at this site. Seismic stratigraphic correlation between Sites 753 and 752 , in conjunction with both sonobuoy and laboratoryderived velocity data $(1800 \mathrm{~m} / \mathrm{s})$, indicates that approximately $190 \mathrm{~m}$ of stratigraphic section was not sampled between the oldest sampled sediment at Site 753 and youngest sediment below the unconformity sampled at Site $\mathbf{7 5 2}$.

A synthetic seismogram at Site 752, for the interval from 110 to $420 \mathrm{mbsf}$, was calculated from downhole sonic and density measurements (see "Seismic Stratigraphy" section, "Site 752" 
A

RC2708 line 20

$\mathrm{N}$
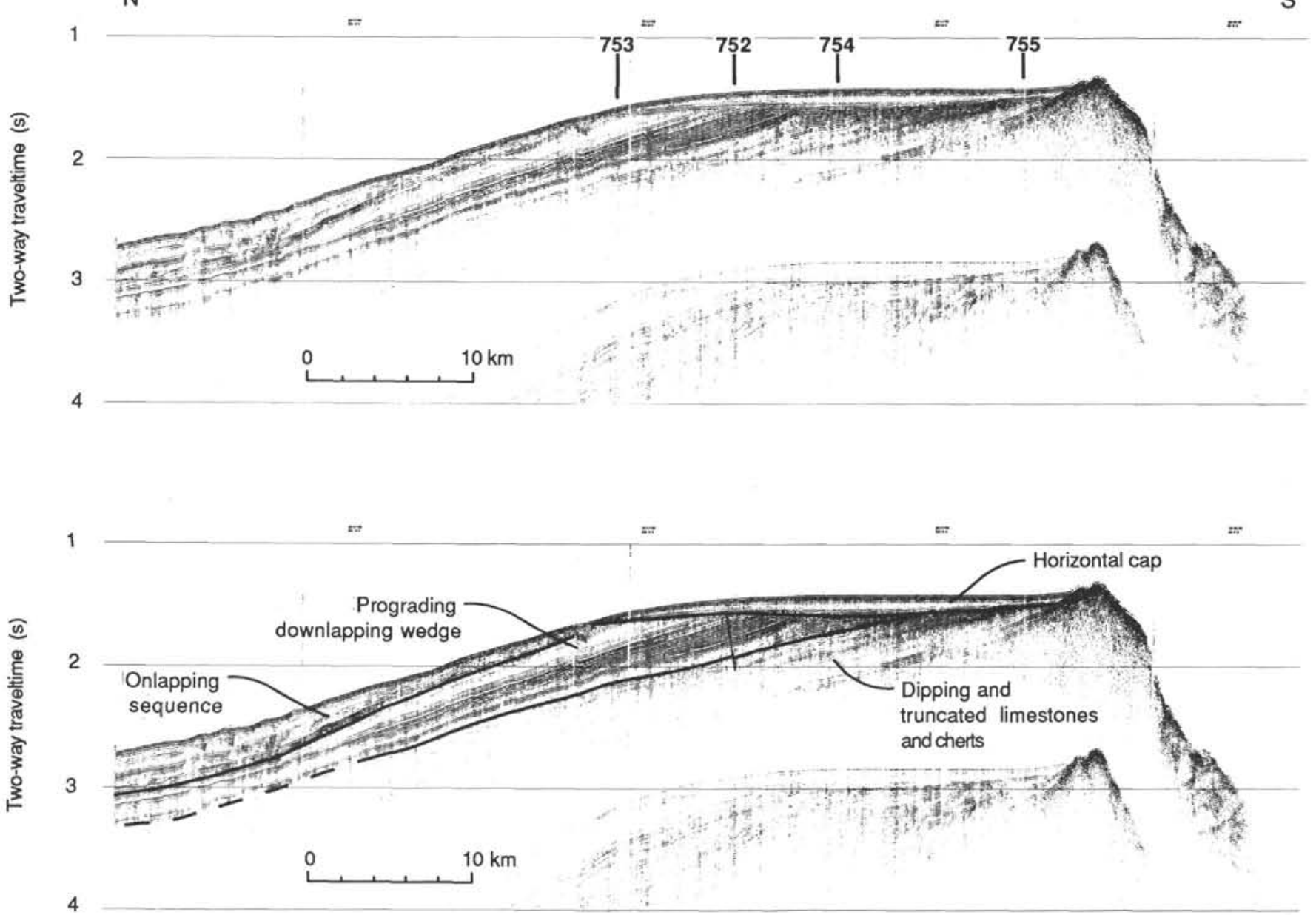

B

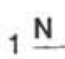

RC2708 line 20

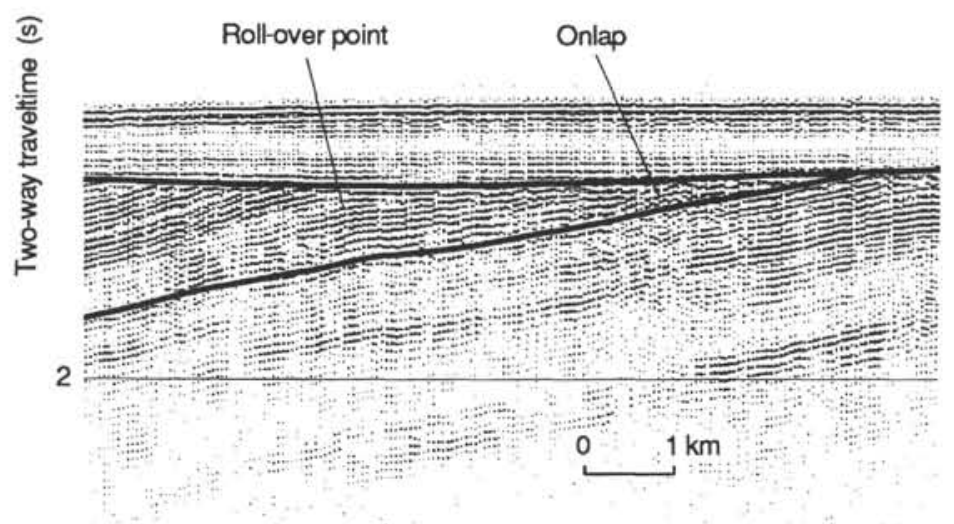

Figure 4. A. Single-channel seismic dip line across Broken Ridge, illustrating the stratigraphic sequences observed on Broken Ridge and their downslope variation. B. Enlargement of the sequence boundary between the dipping and truncated limestones and cherts and the overlying prograding downlapping sequence, which onlaps the pre-existing strata. The subtle change of dip is denoted by the roll-over point. 

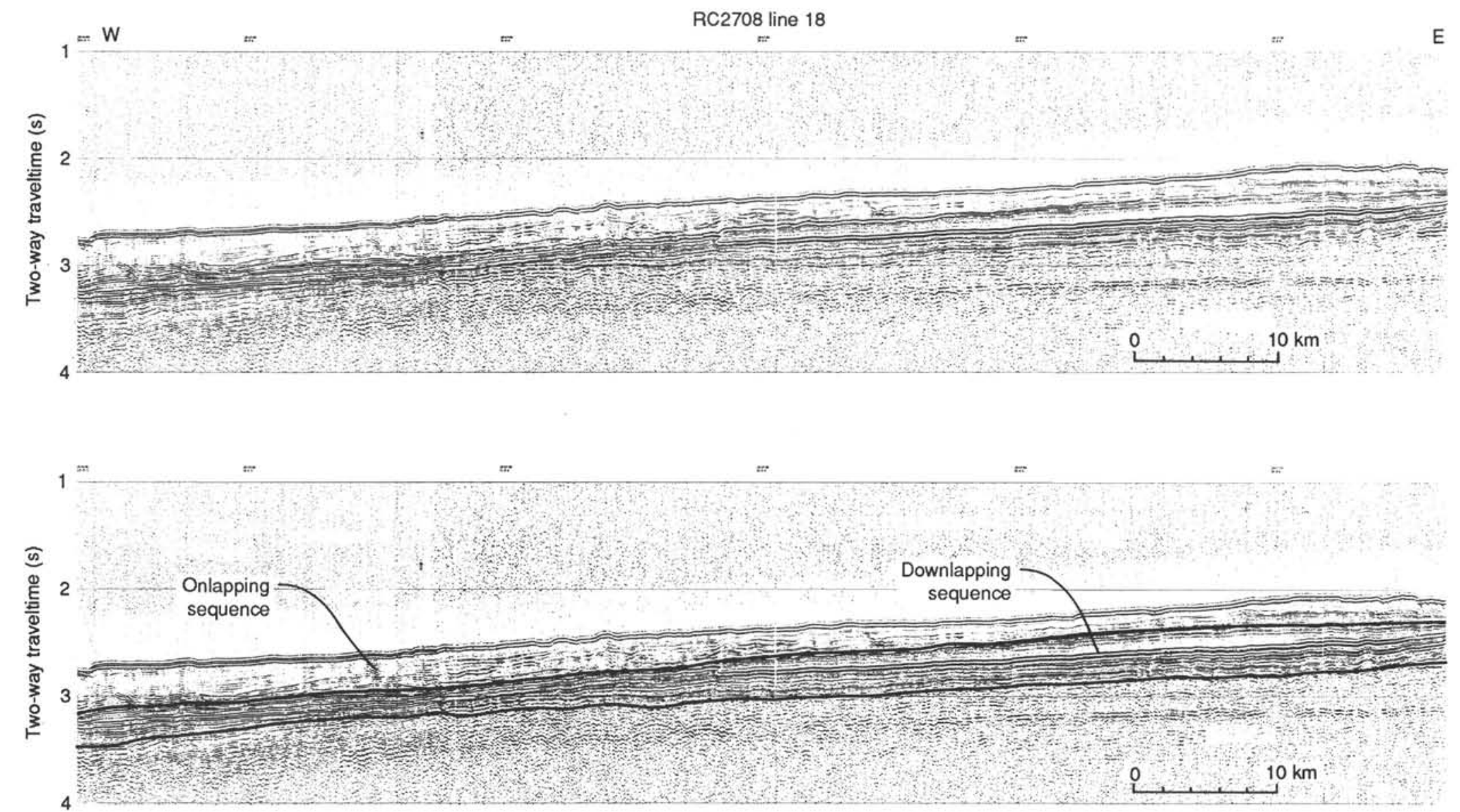

Figure 5. The single-channel seismic strike line on the northern slope of Broken Ridge illustrates the along-slope variation of the stratigraphic sequences. The thickness of the prograding downlapping sequence changes abruptly from east to west. The thickness of onlapping sequence I increases toward the west. 

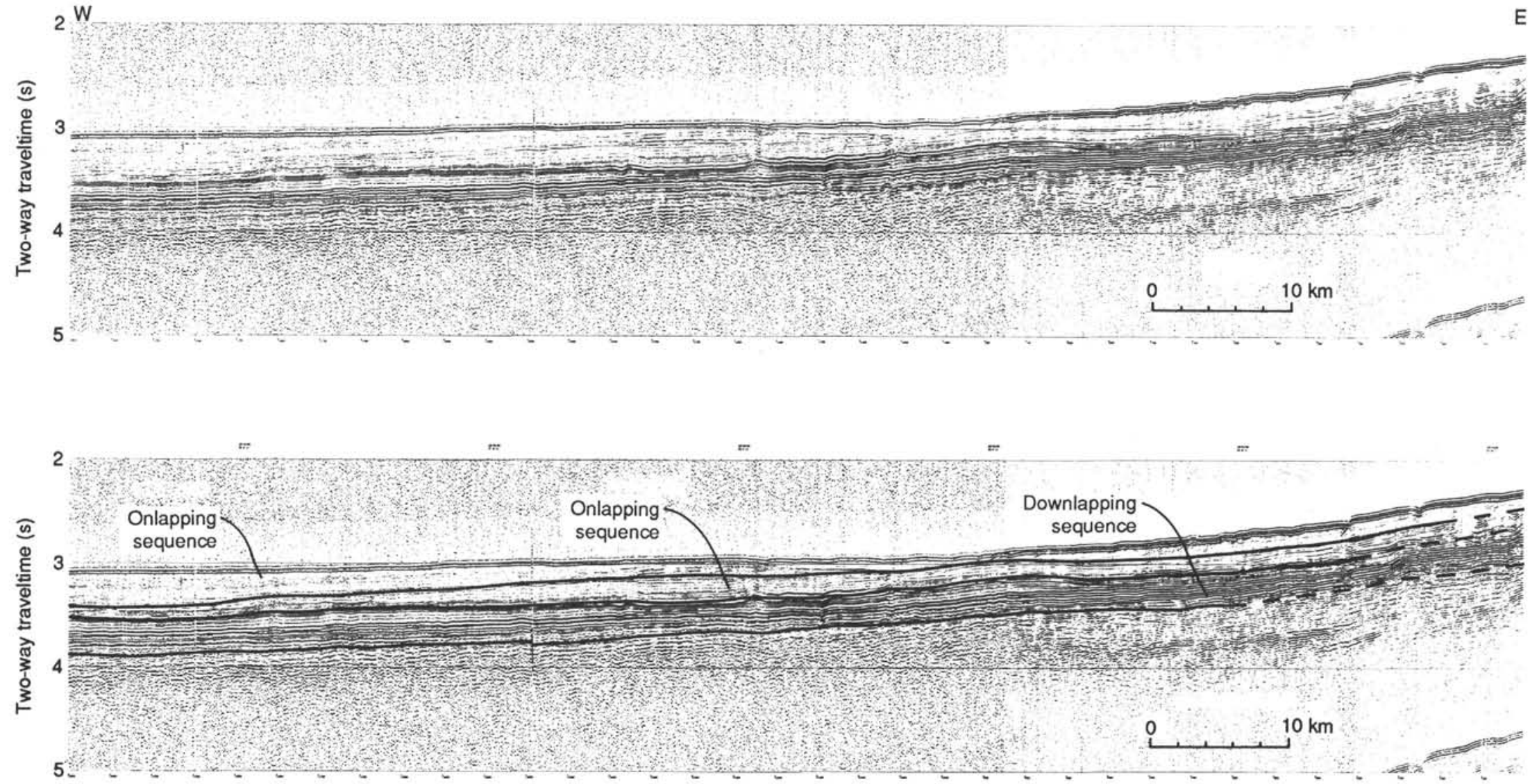

Figure 6. The RC2708 single-channel seismic strike line 12 at the base of the northward-dipping slope of Broken Ridge illustrates the distal variation of the stratigraphic sequences. The prograding downlapping sequence subtly thickens toward the west, and there is a prominent thickness increase in onlapping sequence II, also toward the west. 
Table 2. RC2708 sonobuoy solutions.

\begin{tabular}{|c|c|c|c|c|c|c|c|c|c|c|c|c|c|c|}
\hline \multirow[b]{2}{*}{ Sonobuoy } & \multicolumn{7}{|c|}{ Two-way traveltime ${ }^{\mathrm{a}}$ (s) } & \multicolumn{7}{|c|}{ Velocity ${ }^{\mathrm{b}}(\mathrm{km} / \mathrm{s})$} \\
\hline & H1 & $\mathrm{H} 2$ & H3 & $\mathrm{H} 4$ & H5 & H6 & $\mathrm{H} 7$ & V1 & V2 & V3 & V4 & V5 & V6 & V7 \\
\hline 11 & 1.45 & 1.68 & 2.07 & & & & & 1.63 & 4.19 & 4.97 & & & & \\
\hline 12 & 1.39 & 1.58 & 1.62 & 1.98 & & & & 1.60 & 3.38 & 4.12 & 4.88 & & & \\
\hline 15 & 1.47 & 1.60 & 1.80 & 1.89 & 1.97 & 2.06 & & 1.61 & 1.84 & 2.10 & 3.07 & 3.68 & 4.35 & \\
\hline 16 & 1.41 & 1.51 & 1.78 & 1.89 & 1.95 & 2.49 & & 1.64 & 1.90 & 3.07 & 3.67 & 4.62 & 5.03 & \\
\hline 17 & 1.41 & 1.49 & 1.58 & 1.87 & 1.95 & 2.02 & 2.34 & 1.55 & 1.61 & 2.20 & 3.06 & 3.56 & 4.49 & 4.94 \\
\hline${ }^{c} 32$ & 1.42 & 1.58 & 1.77 & 1.90 & 2.36 & & & 1.63 & 2.18 & 3.29 & 4.25 & 4.96 & & \\
\hline 35 & 2.98 & 3.21 & 3.38 & 3.58 & & & & 1.63 & 1.70 & 1.84 & 3.86 & & & \\
\hline 36 & 3.05 & 3.30 & 3.42 & 3.72 & & & & 1.63 & 1.69 & 1.85 & 3.83 & & & \\
\hline 50 & 1.53 & 1.62 & 1.82 & 1.94 & 2.07 & 2.14 & 2.62 & 1.66 & 1.85 & 2.03 & 2.96 & 3.58 & 4.52 & 4.85 \\
\hline 51 & 1.66 & 1.73 & 1.90 & 2.05 & 2.19 & 2.28 & & 1.62 & 1.90 & 2.12 & 3.00 & 3.60 & 4.49 & \\
\hline 54 & 1.80 & 1.96 & 2.18 & 2.34 & 2.44 & & & 1.60 & 1.63 & 2.22 & 3.13 & 3.69 & & \\
\hline$c_{59}$ & 1.73 & 1.92 & 2.12 & 2.31 & 2.59 & & & 1.61 & 2.15 & 3.18 & 4.07 & 4.92 & & \\
\hline${ }^{\mathrm{c}} 60$ & 1.43 & 1.55 & 1.65 & 1.89 & 2.31 & & & 1.56 & 1.65 & 3.09 & 4.44 & 4.88 & & \\
\hline${ }^{c} 61$ & 1.41 & 1.54 & 1.85 & & & & & 1.59 & 3.63 & 4.40 & & & & \\
\hline
\end{tabular}

${ }^{a} \mathrm{H}=$ horizon.

${ }^{b} \mathrm{~V}=$ velocity interval.

${ }^{\mathrm{c}}$ Deployed on dip lines.

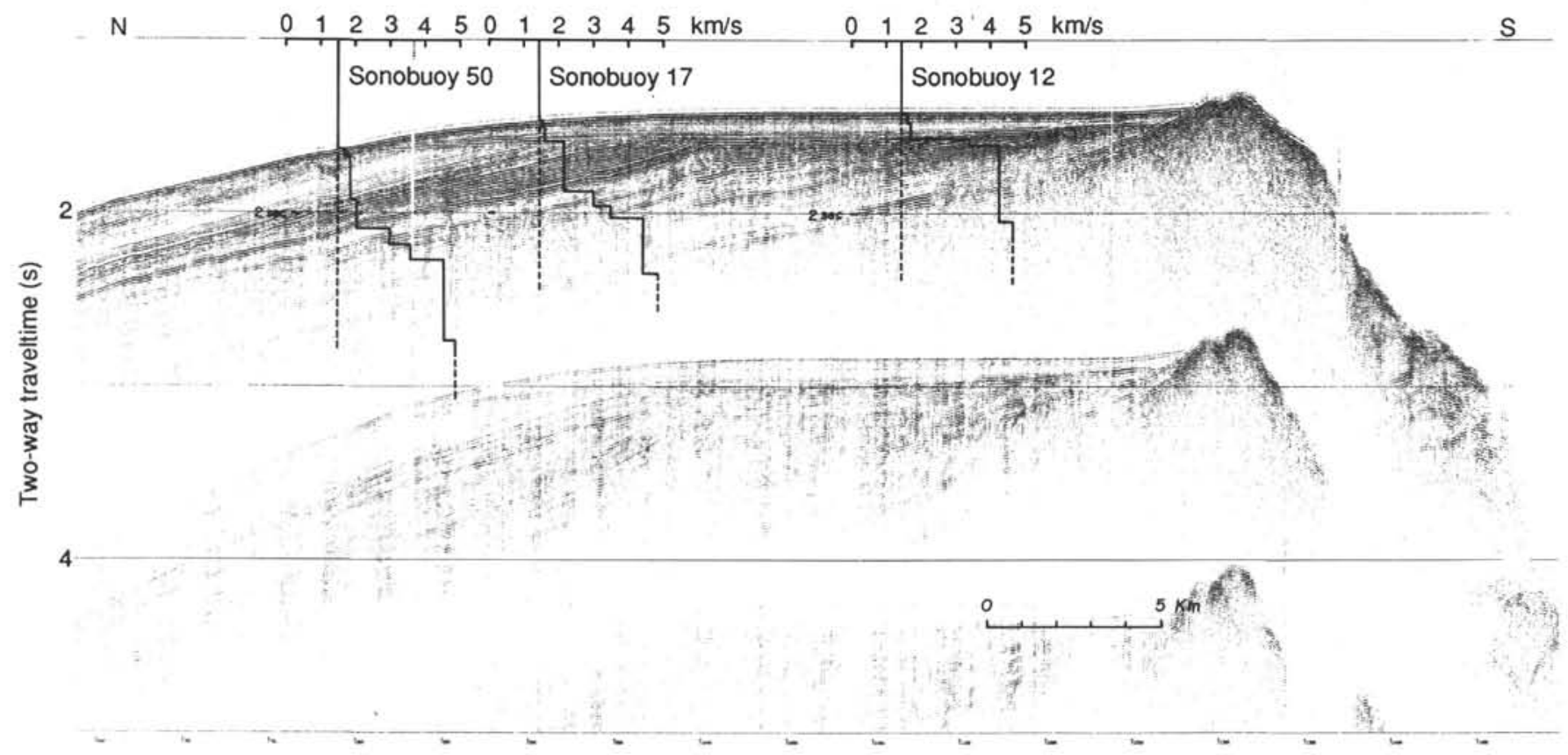

Figure 7. Sonobuoy velocity solutions from the intersecting strike lines are projected onto the dip line (RC2708 seismic line 20), with corrections for changes in water depth. The downsection velocity gradient is also manifested downslope in response to the subcropping reflectors. The prominent velocity gradient in these velocity profiles correlates with the sequence boundary between the dipping and truncated limestones and cherts and the prograding downlapping sequence.

chapter). A zero-phase Ricker wavelet was convolved with the downhole acoustic impedance contrast to generate the synthetic seismogram. The synthetic seismogram is in good agreement with the observed seismic-reflection data in reflector position (see Fig. 37 in "Seismic Stratigraphy" section, "Site 752" chapter). The high-amplitude reflectors in the middle highly reflective unit result from ash layers and silica-rich layers interbedded with the nannofossil calcareous chalks. Laboratory and downhole-derived acoustic impedance contrasts correlate with these lithologic contacts (see "Physical Properties" and "Geophysical Well Logging" sections, "Site 752" chapter). Several distinct porcellanite layers in Cores 121-752B-6R through 121-752B-9R (320-340 mbsf) produce faint seismic reflectors at those depths. The ash content of the sediment increases downsection, with a noticeable increase beginning approximately in the upper Paleo- cene section ( 56-60 Ma) (see the "Sedimentary Record of Broken Ridge" section of the "Broken Ridge Summary" chapter, this volume).

Site 754 is approximately $5 \mathrm{~km}$ south of Site 752 (Fig. 4A). Seismic-reflection, paleomagnetic, and microfossil data suggest that approximately $20 \mathrm{~m}$ of stratigraphic overlap exists between Sites 752 abd 754. Almost $200 \mathrm{~m}$ of lower to upper Maestrichtian limestone and chalk with interspersed horizons of ash and chert was recovered at Site 754.

A synthetic seismogram at Site 754 , for the interval from 150 to $300 \mathrm{mbsf}$, was calculated from downhole sonic measurements and a constant density (see "Seismic Stratigraphy" section, "Site 754" chapter). The synthetic seismogram is in good agreement with the observed seismic-reflection data in position but not in amplitude (see Fig. 26, "Seismic Stratigraphy" section, "Site 

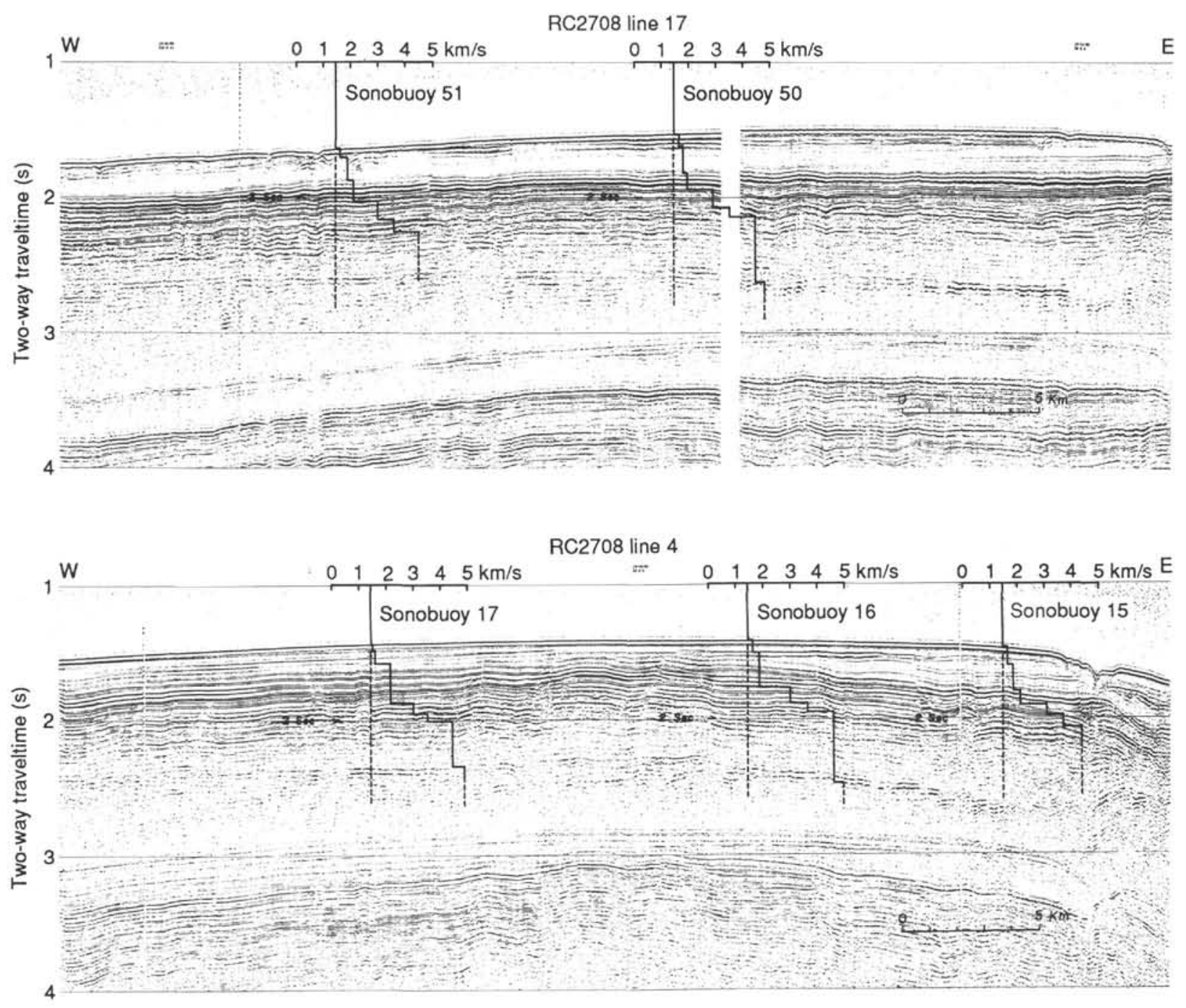

RC2708 line 3

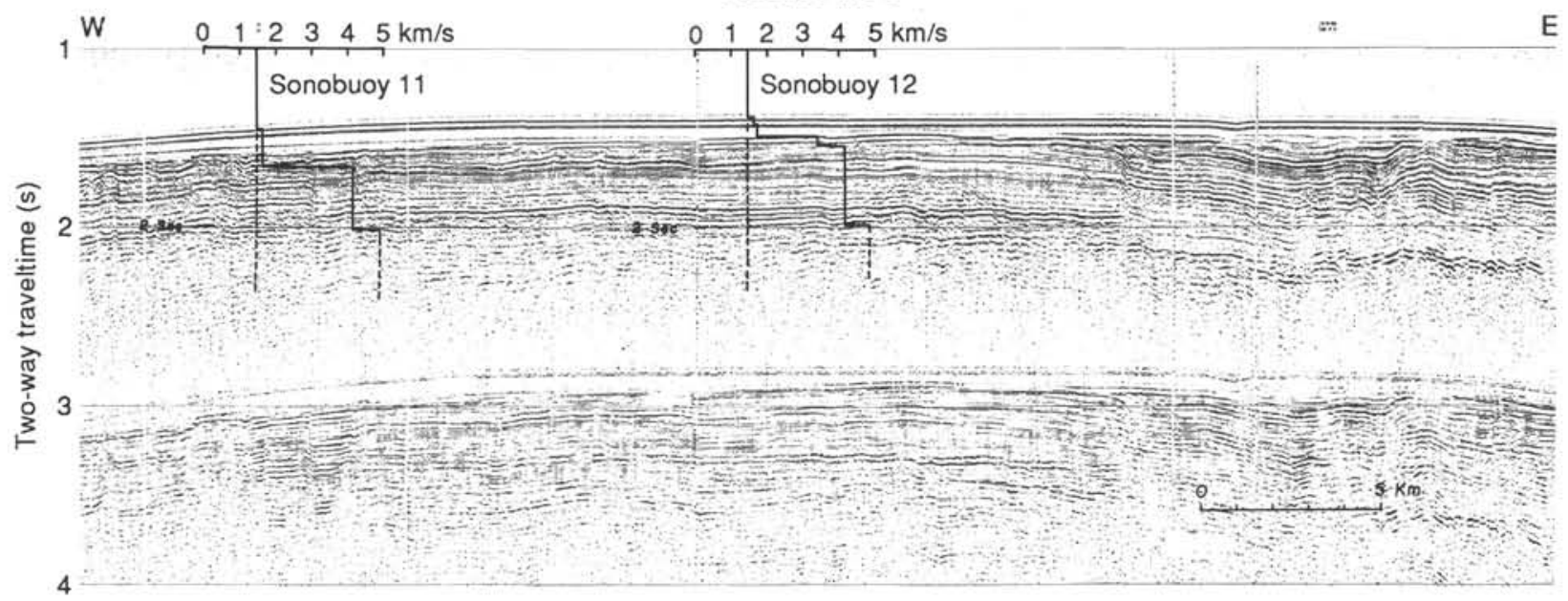

Figure 8. Sonobuoy velocity solutions shown on the appropriate strike lines. 


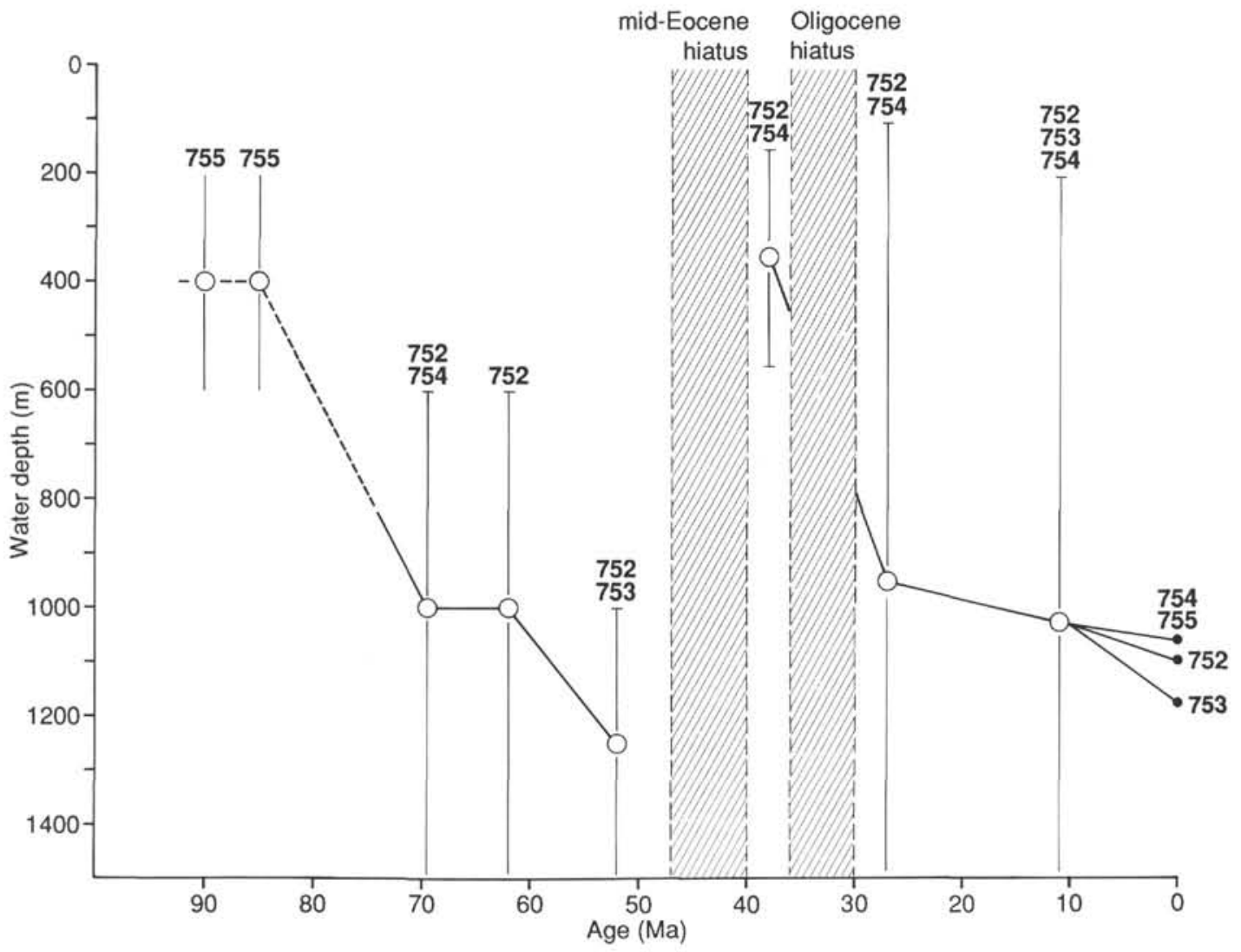

Figure 9. Estimates of paleodepth for ODP Sites 752 through 755 , based on benthic foraminifers (see respective site chapter "Biostratigraphy" sections). The open circles denote depth estimates from the most abundant benthic foraminifer in the sample, and the vertical lines represent the range of water-depth estimates for all of the benthic foraminifers in the sample.

754" chapter). The reflectors in the lower weakly laminated unit arise from a downsection increase in the degree of induration from a chalk to a limestone between Cores 121-754B-8R and 121-754B-9R (see "Lithostratigraphy and Sedimentology" section, "Site 754" chapter) and from a few interbedded ash and ash-rich intervals. The ash-bearing limestones are noticeably less indurated than the ash-barren limestones. The lower reflector (couplet) arises from a change in lithology from an ash-rich limestone to a limestone with interbedded chert ("Lithostratigraphy and Sedimentology" section, "Site 754" chapter).

The benthic foraminifer data indicate that water depths were increasing during the deposition of the prograding downlapping wedge (Fig. 9). The water depth was approximately upper bathyal at the onset of deposition and increased to middle/lower bathyal depths toward the cessation of deposition for this sequence (Fig. 9). Although the range of depths estimated from the benthic foraminifers is great, the overall depth trend suggests that water depths were increasing during the deposition of this sequence.

\section{Onlapping Sequence I}

The thickest accumulations ( $>300 \mathrm{~m}$ ) of onlapping sequence I are ponded toward the west at the toe of the ridge, infilling the pre-existing structural low (Figs. 11A and 11B). The bypassing sediments, presumed to be a consequence of the steeper slope gradient, generated a depositional lens that shifts the 2600- and 2700-m contours basinward (Fig. 11B). The depocenter for onlapping sequence $I$ is at the base of the pre-existing slope, upslope from the previously mentioned depositional lens (Figs. $10 \mathrm{~A}$ and $11 \mathrm{~A})$.
A downward shift in coastal onlap has been used by many researchers to estimate changes in eustatic sea level (Vail et al., 1977; Vail, 1987; Haq et al., 1987). However, the change in position of coastal onlap is critically dependent on changes in the rates of subsidence, eustatic sea level, and sediment supply (Pitman, 1978) instead of resulting from absolute changes in eustatic sea level. The chaotic internal structure within the onlapping sequence, as seen in Figure 4A and termed onlapping sequence I, may arise from the interaction of many downslope dispersal patterns that overlap and interfinger. Smaller-scale structures appear to be post-depositional rotational slumps (Fig. 4A). The only submarine canyons observed in the study region incise the prograding downlapping sequence and are spatially concentrated along the northern edge of the platform (Fig. 4A). Downward shifts in onlap below the depositional coastal break and evidence for subaerial and submarine erosion (initiation of canyon cutting) are criteria cited by Vail et al. (1984) for the identification of a type 1 sequence boundary, which implies a pronounced increase in the rate of relative sealevel fall.

Onlapping sequence I is truncated and onlapped by a second sequence (onlapping sequence II) that appears to be the result of ubiquitous slumping toward the eastern segment of Broken Ridge (Fig. 6).

\section{Onlapping Sequence II}

The $3.5-\mathrm{kHz}$ and water gun seismic records illustrate the prevalent slump scars throughout the eastern part of Broken Ridge. Most of the slump scars are restricted to the onlapping sequences (Fig. 6). The debris/turbidity flows associated with 

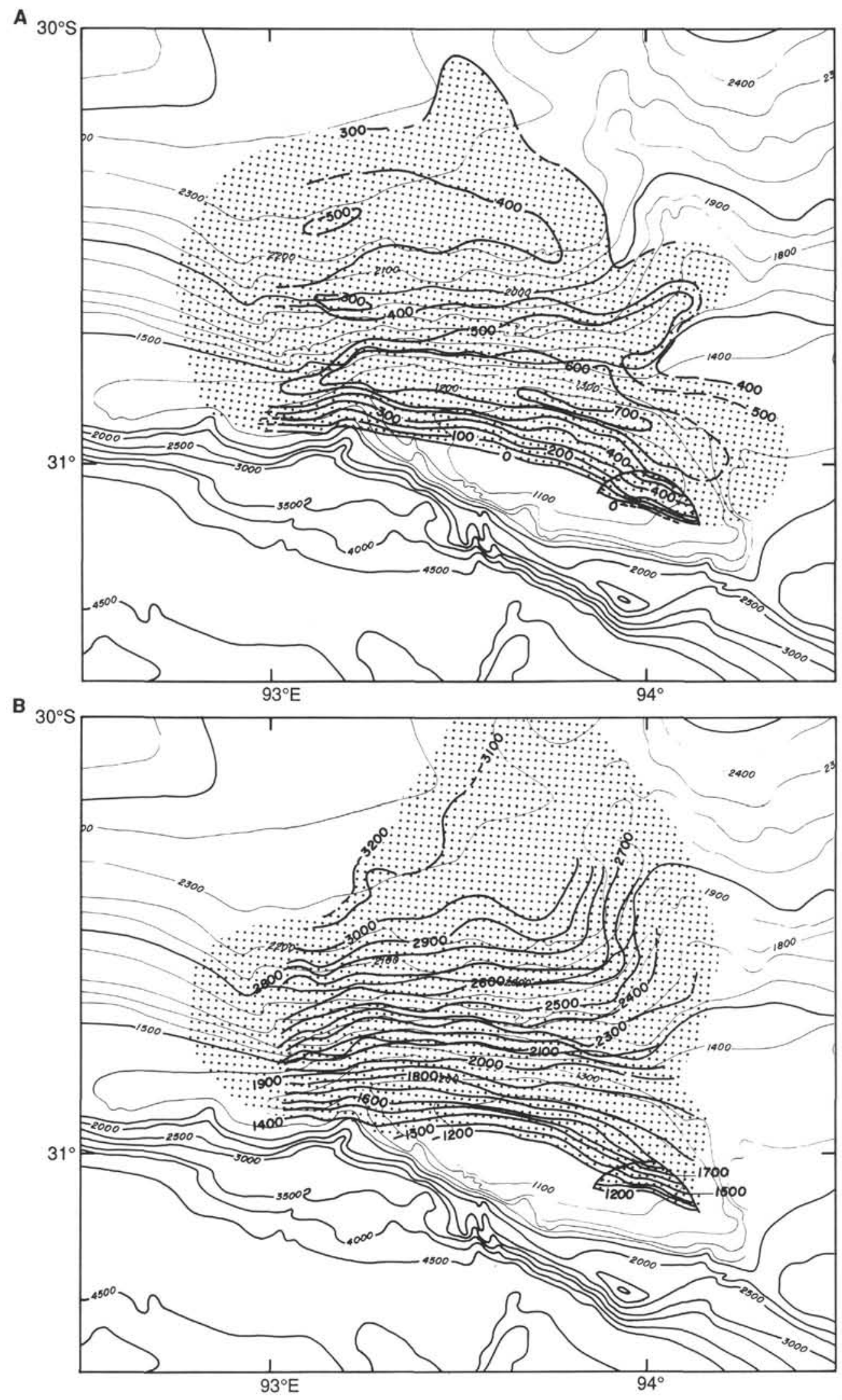

Figure 10. Prograding downlapping sequence. A. Isopach map showing the sedimentary depocenter on the eastern segment of the ridge. An increase in sediment thickness toward the west at the base of the ridge is outlined by the $400-\mathrm{m}$ isopach. B. Structure contour map to the base of the prograding downlapping sequence illustrates the uniformly dipping slope. A prominent spoon-shaped normal fault occurs on the eastern part of the plateau. 


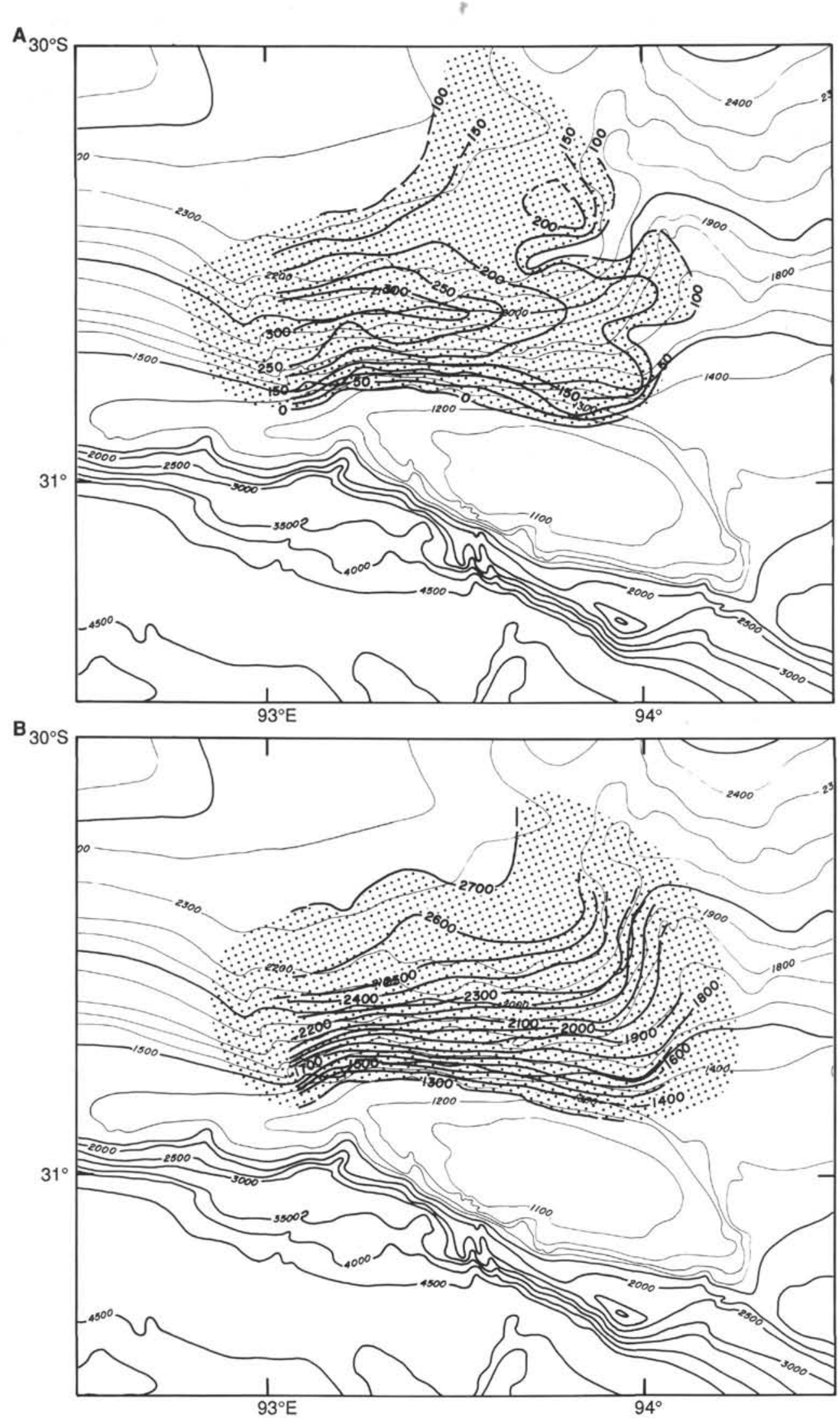

Figure 11. Onlapping sequence I. A. Isopach map showing the depocenter at the base on the northwestern slope of Broken Ridge. B. Structure contour map to the base of the sequence exhibits the east to west change in slope gradient. The structural low is adjacent to the western part Broken Ridge. 
these slump scars coalesce in the paleostructural lows and onlap sequence I. The finely laminated acoustic character of the second onlapping sequence, onlapping sequence II, suggests that a high degree of liquefaction must have occurred prior to deposition of the sediment. The acoustic character and thickness suggest that a multitude of unchannelized debris/turbidity flows have coalesced to create this sequence. The thickest accumulation for onlapping sequence II is shifted northward relative to the depocenter for onlapping sequence I (Figs. 11A and 12). The stratigraphic succession between onlapping sequences I and II is apparent from the stratal patterns exhibited between them. In contrast, determination of the stratigraphic relationship between onlapping sequence II and the horizontal cap that rests above the angular unconformity is difficult.

\section{Horizontal Cap}

The horizontal cap sequence rest unconformably on the dipping and truncated limestone, chalk, chert, and tuff sequence and the truncated prograding downlapping sequence (Figs. 3B and 4A). Asymmetric sediment erosion around the crest of Broken Ridge may document the influence of the eastward-flowing Antarctic Circumpolar Current (ACC; Fig. 3A) (Kennett, 1979; Kennett and Burns, 1972). The depocenter for the horizontal cap occurs over the weakly laminated unit (the basal unit of the prograding downlapping sequence; Fig. 13A). The horizontal cap onlaps the truncated sequences and thus, becomes progressively thinner away from the center of the ridge. However, a small isolated basin south of the main platform, corresponding to the small basin drilled by DSDP Site 255 (Davies, Luyendyk, et al., 1974), received a thicker sequence of sediments than the other regions equidistant from the depocenter ( $>50 \mathrm{~m}$; Fig. 13A). Differential deposition toward the western segment of the ridge may be a result of enhanced currents in the region around an incised section (i.e., canyon) on the southern scarp (Fig. 13A).

The depth to the angular unconformity defines a structural low over the weakly laminated unit (Fig. 13B). The depth of the angular unconformity shoals toward both the north and south, away from the structural low (Fig. 13B). The outer high depicted by the 1150 -m contour spatially coincides with the depocenter for the underlying prograding downlapping unit (Figs. $10 \mathrm{~A}$ and $13 \mathrm{~B}$ ). The contrast in compressional-wave velocity between the prograding downlapping sequence and the truncated limestones and cherts indicates a substantial difference in the degree of induration (Figs. 7 and 8 and Table 2). If the truncation of these units resulted from the same erosional event, then it is interesting that the less indurated, prograding downlapping sequence was not eroded more than the dipping limestone, chalk, chert, and tuff sequence (Figs. 3B and 4). This differential erosion suggests that prior to truncation, the prograding downlapping wedge was considerably thicker or at greater depths below wave base.

A foraminifer nannofossil ooze was recovered from above the prominent angular unconformity at Sites 752 through 755 . The most complete stratigraphic section was recovered at Site 754 and consists of approximately $130 \mathrm{~m}$ of Pleistocene to upper Eocene foraminifer nannofossil ooze, in which foraminifers become less abundant and micrite becomes more abundant with depth. Most of the reflectors within the horizontal cap coincide with changes in the mean grain size of the bulk sediment, and the coarser grain size may indicate winnowed layers (see "Litho-

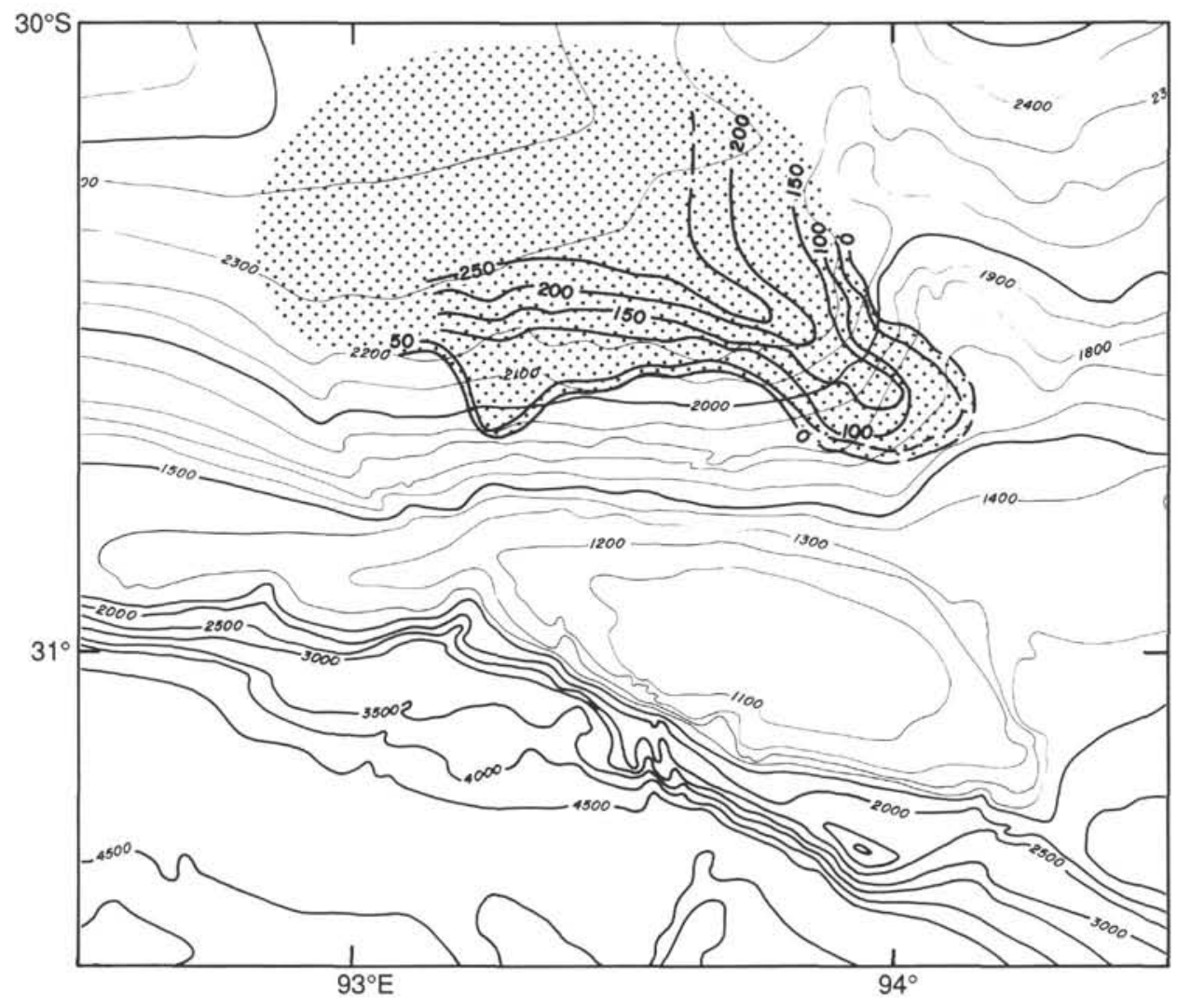

Figure 12. Isopach map of onlapping sequence II, which appears to be a multitude of coalescing slumps. The depocenter is shifted distally with respect to onlapping sequence I as a result of the progressive infilling of the basin by the gravity-driven flows. 


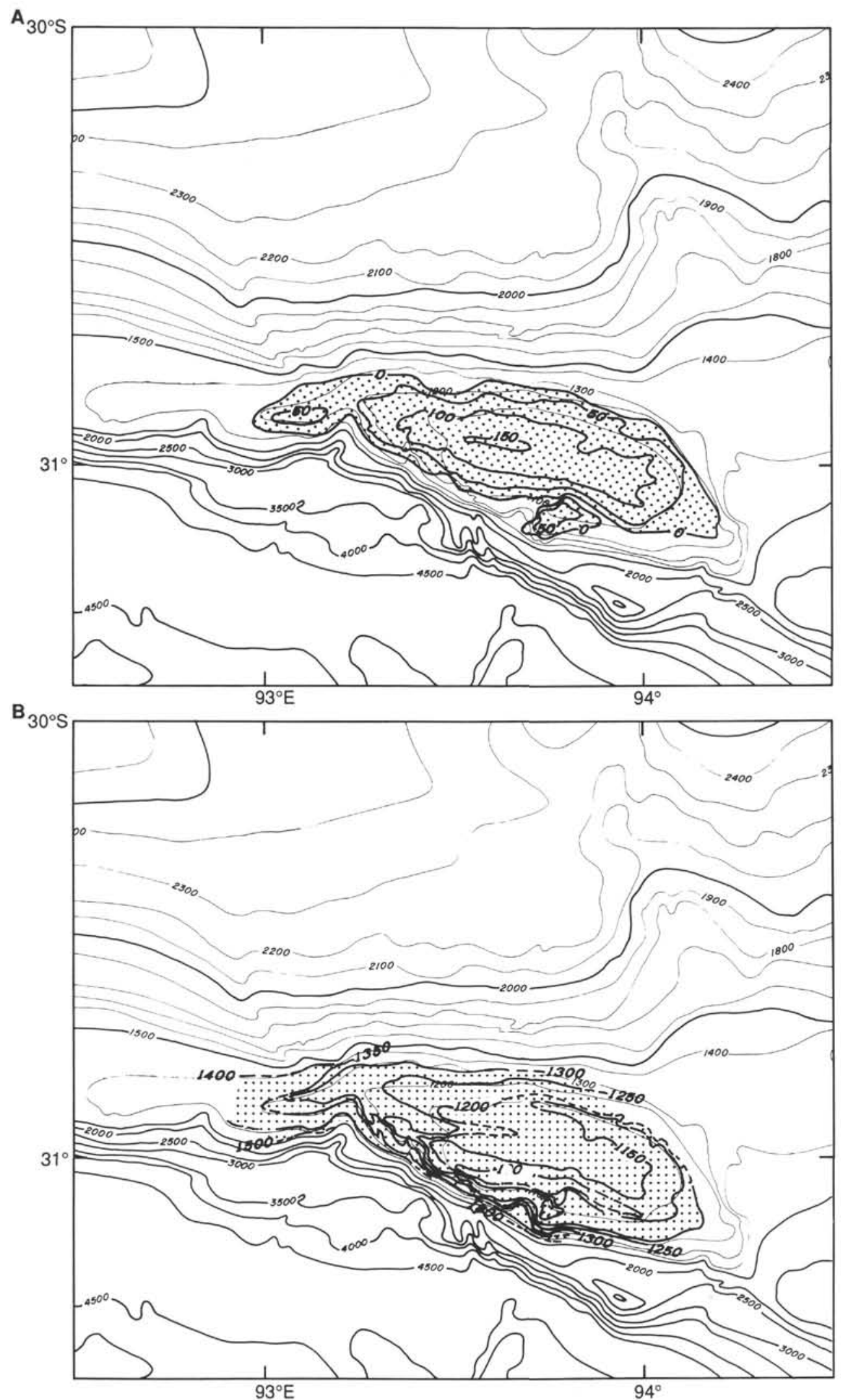

Figure 13. Horizontal cap sequence. A. Isopach map showing that the thickest sediment accumulation occurred over the weakly laminated downlapping unit. The small rider block basin contiguous with the main platform was sampled at DSDP Site 255; the stratigraphy developed in this basin might have no correlative stratigraphy on the main platform. B. Structure contour map to the top of the angular unconformity shows that an outer high developed on the northeastern edge of the platform. The spatial distribution of the outer high is coincident with the depocenter for the underlying unit. 
stratigraphy and Sedimentology" sections, "Site 752" through "Site 754" chapters). These reflectors can be correlated among Sites 752,753 , and 754 . However, these reflectors cannot be traced laterally to Site 755 , either because they become too diffuse to identify reliably or because they onlap the dipping and truncated limestone, chalk, chert, and tuff sequence (see Fig. 15 of the "Seismic Stratigraphy" section, "Site 755" chapter).

Two hiatuses have been identified from ODP drilling and seismic-reflection data. The upper hiatus occurs within the cap, and the lower hiatus delineates the base of the horizontal Neogene cap. At both Sites 752 and 754, the upper hiatus separates limestone pebbles in an upper Eocene ooze from the overlying upper Oligocene nannofossil ooze. In contrast, at Sites 753 and 755 , the two hiatuses coalesce, thus increasing the hiatal duration at these sites.

The duration of the earlier hiatus increases across Broken Ridge toward the south, as evidenced by the truncation of older dipping strata in this direction (Fig. 4A). At Site 753, the northernmost site, the hiatus separates middle Eocene nannofossil chalk with foraminifers from the overlying lower Miocene ooze with limestone pebbles (see "Seismic Stratigraphy" section, "Site 753 ” chapter). The hiatus at Site 752, however, separates lower Eocene nannofossil calcareous chalk from overlying upper Eocene ooze ("Seismic Stratigraphy" section, "Site 752" chapter). Farther south at Site 754, the hiatus separates upper Maestrichtian calcareous chalk from overlying upper Eocene cherty gravels ("Seismic Stratigraphy" section, "Site 754" chapter), and at Site 755 , the hiatus separates a middle lower Santonian tuff with interbedded ashy limestone from an overlying lower Miocene(?) shelly foraminifer grainstone ("Seismic Stratigraphy" section, "Site 755" chapter).

The benthic foraminifer data indicate that water depths were increasing prior to the middle Eocene hiatus and then rapidly shoaled (Fig. 9). Flexural models for Broken Ridge (Weissel and Karner, in press) predict approximately $2200 \mathrm{~m}$ of uplift during the middle Eocene rifting event at the main south-facing escarpment. Subsequent to rifting, the water depths increased precipitously (Fig. 9).

\section{GRAVITY DATA INTERPRETATION}

Broken Ridge is the bordering flank topography of a midEocene rift system and is the result of either (1) the flexural rebound of the Broken Ridge region during extension of the lithosphere, with rebound implying a significant flexural strength of the lithosphere during rifting; (2) topographic uplift supported by rift-induced heat at the base of the lithosphere beneath Broken Ridge; or (3) topographic support by thickened crust, with the thickening as the consequence of a magmatic "underplating" process. For mechanisms (2) and (3), maximum uplift is generated for a lithosphere that does not possess flexural strength, that is, the rift flank topography is locally compensated. In this case, the resulting free-air gravity anomalies tend to have a low amplitude. In contrast, mechanism (1) tends to maximize both the topographic uplift and the free-air gravity anomaly. Consequently, the observed free-air gravity anomaly across Broken Ridge can possibly discriminate between local (low flexural strength) and regional (high flexural strength) isostatic schemes for the support of the plateau.

Figure 14 summarizes the topography and respective free-air gravity anomaly profiles obtained during the RC2708 site survey of Broken Ridge. The peak-to-trough free-air gravity response of Broken Ridge is $140-160 \mathrm{mgal}$, which is associated with a topographic range of 3500 to $4000 \mathrm{~m}$. The free-air gravity anomaly shows the usual "edge-effect" shape characteristic of most passive margins (e.g., Karner and Watts, 1982) and is diagnostic of the marked change in crustal thickness from the southeast Indian Ocean seafloor (crustal thickness of approximately $6 \mathrm{~km}$ ) to the Broken Ridge Plateau (crustal thickness of 18-20 km; Francis and Raitt, 1967). The edge-effect gravity anomaly is basically responding to this regional (i.e., long wavelength) change in topographic level. However, it is not clear how shorter wavelength topographic features, such as the uplifted topography adjacent to the south-facing escarpment, contribute to the observed gravity anomaly.

To address this question, we modeled the gravity effect over Broken Ridge by calculating the crustal thickness across the region assuming local isostasy and a crustal column in balance with the adjacent oceanic crust, viz., a 6-km crust in local isostatic balance with a $4.5-\mathrm{km}$ water column. Typical oceanic crust associated with seafloor-spreading magnetic anomalies occurs just south of the southern margin of Broken Ridge (anomaly 18; Mutter and Cande, 1983; Mutter et al., 1985). We selected this region as a reference to avoid any anomalous bathymetric effects associated with Broken Ridge and the younger ocean crust to the south. The thickness of the crust across the Broken Ridge Plateau and adjacent ocean crust can be calculated using the equation

$$
t(x)=\frac{\left(d_{r e f}-d(x)\right)\left(\rho_{m}-\rho_{w}\right)+t_{r e f}\left(\rho_{m}-\rho_{c}\right)}{\left(\rho_{m}-\rho_{c}\right)},
$$

where $t(x)$ and $d(x)$ are the crustal thickness and the depth of the seafloor at point $(x)$, respectively; $t_{\text {ref }}$ and $d_{\text {ref }}$ are the crustal thickness and the water depth at the reference point, respectively, and $\rho_{w}, \rho_{c}$, and $\rho_{m}$ are the water, crust, and mantle densities, with respective values of $1.03,2.8$, and $3.33 \mathrm{~g} / \mathrm{cm}^{3}$. The locally compensated crust/mantle interface, $r(x)$, is simply

$$
r(x)=t(x)+d(x) .
$$

Once the crust/mantle interface, $r(x)$, has been determined, the free-air gravity effect over the compensated system can be calculated using either the usual two-dimensional line-integral methods (e.g., Talwani et al., 1959) or the Fourier domain approach of Parker (1973).

Figure 15A compares the observed gravity anomaly with the calculated gravity effect for the locally compensated topographic model for Broken Ridge. Large amplitude discrepancies exist between the observed and calculated gravity of approximately $50 \mathrm{mgal}$ over the crest of Broken Ridge. The small shift in the modeled free-air gravity effect relative to the observed gravity anomaly appears to be related to the rider block basin on the southern scarp of Broken Ridge, a feature completely ignored in the observed gravity. We conclude from Figure $15 \mathrm{~A}$ that the rift flank topography of Broken Ridge is not compensated by a negative density contrast at depth. Consequently, the rift flank topography cannot be supported by either thermal processes or thickened crust. Crustal thickening by underplating is therefore rejected. The large amplitude of the observed relative to the calculated free-air gravity anomaly implies that the topography is not locally compensated.

In contrast, a model in which the Broken Ridge region is flexurally unloaded during extension by the removal of the Kerguelen-Heard Plateau adequately predicts both the free-air gravity and the topography (Fig. 15B) for an effective elastic thickness of the lithosphere $\left(T_{e}\right)$ of $15-20 \mathrm{~km}$. The important feature of our flexural rebound model is that the Moho approximately parallels the surface topography, in marked contrast to the usual isostatic schemes that require an inverse relationship between Moho and surface topographies. The unloading process and gravity calculation were modeled using techniques developed by Weissel and Karner (in press). The critical conclusion drawn from Figure 15B is that the Moho topography approximately parallels the surface rift flank topography and thus is a flexural 


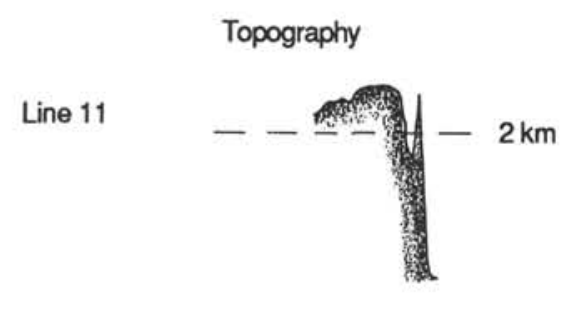<smiles>[CH][TeH]</smiles>
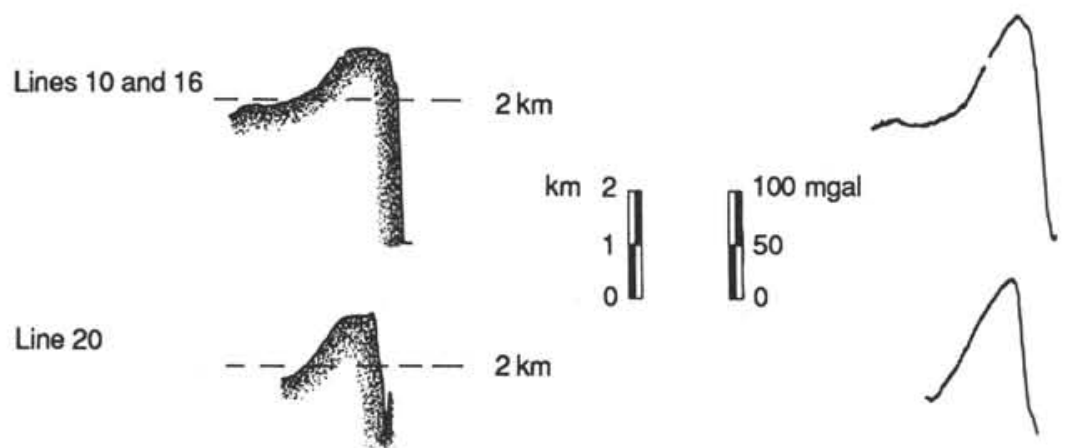

Line 20
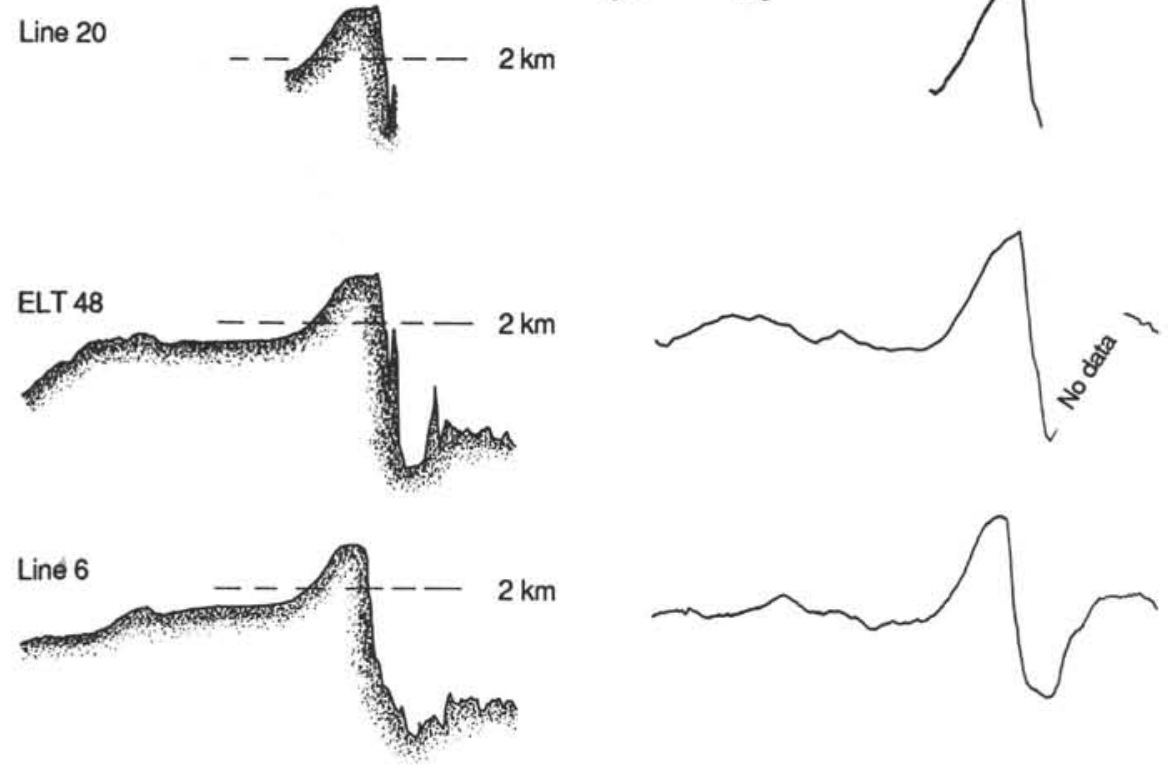

Line 21

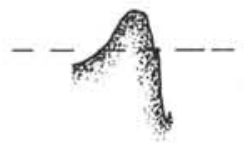

$2 \mathrm{~km}$
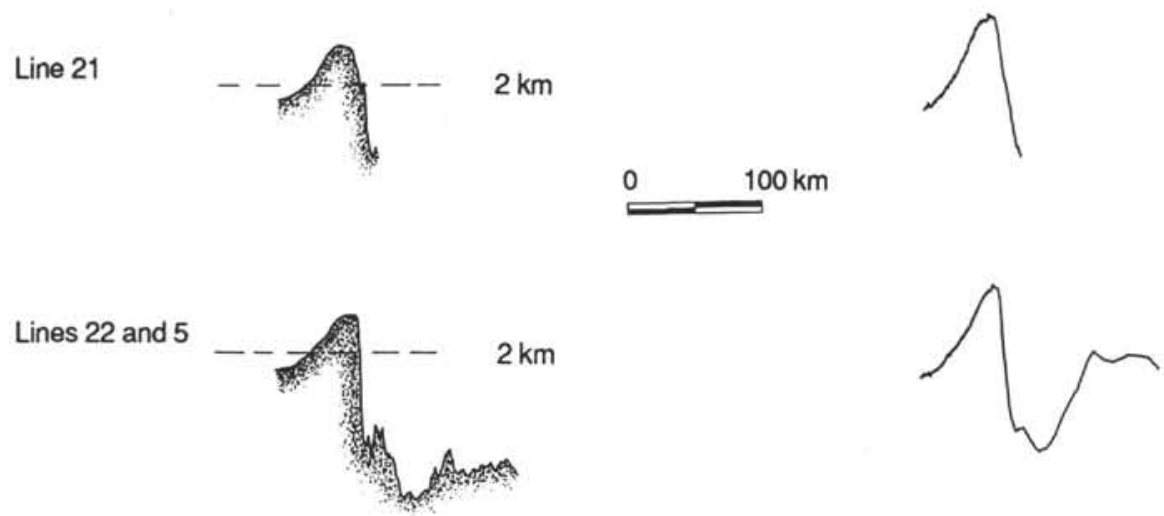

Figure 14 . Topography and free-air gravity anomaly profiles obtained by RC2708 across the Broken Ridge Plateau.

effect. Flexural support of topography implies that the lithosphere retained finite flexural strength during (and following) the extension process.

In summary, modeling the free-air gravity anomaly over Broken Ridge suggests that the topography is basically uncompensated in the sense that the Moho topography parallels the bathymetry. This is direct evidence for a lithosphere with finite flexural strength. Contrary to earlier studies (e.g., Barton and Wood, 1984), extended lithosphere can retain finite flexural strength during the rifting process such that the rift-induced to- pography is preserved. Finite lithospheric strength during rifting can account for the tectonic uplift of Broken Ridge (the footwall block) by the southerly removal of the hanging-wall block (Kerguelen-Heard Plateau).

\section{UPLIFT AND SUBSIDENCE HISTORY OF BROKEN RIDGE}

At the time of rifting, Broken Ridge Plateau had subsided to water depths greater than $1000 \mathrm{~m}$ (Fig. 9). If this water depth represents thermally re-equilibrated lithosphere, then a $1.0-\mathrm{km}$ 
A

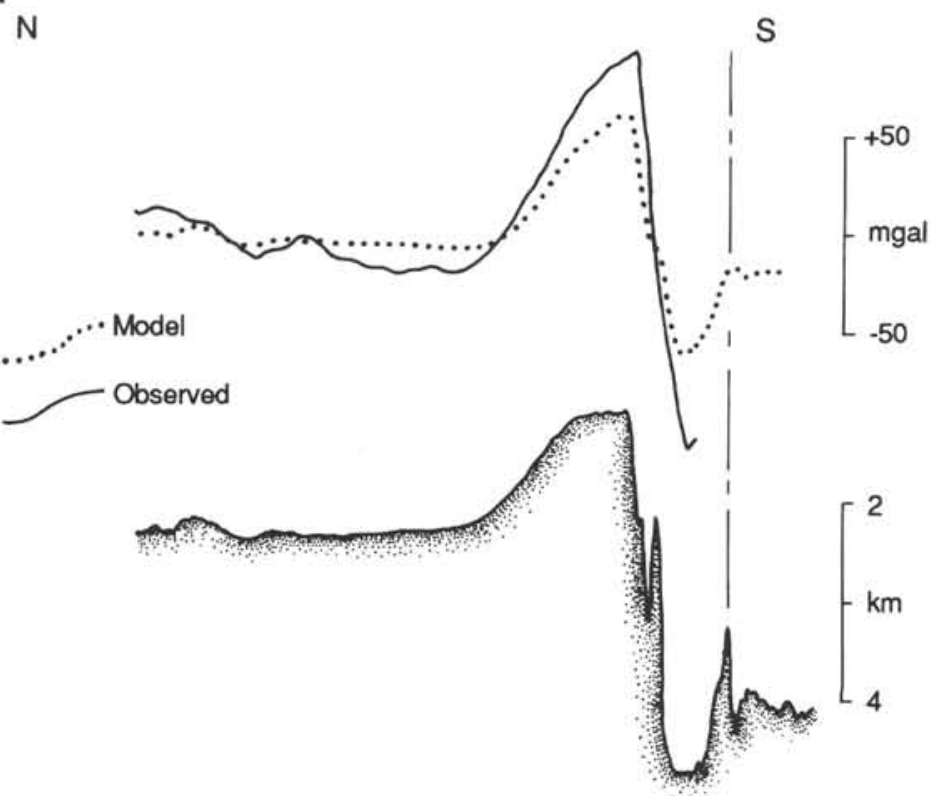

B

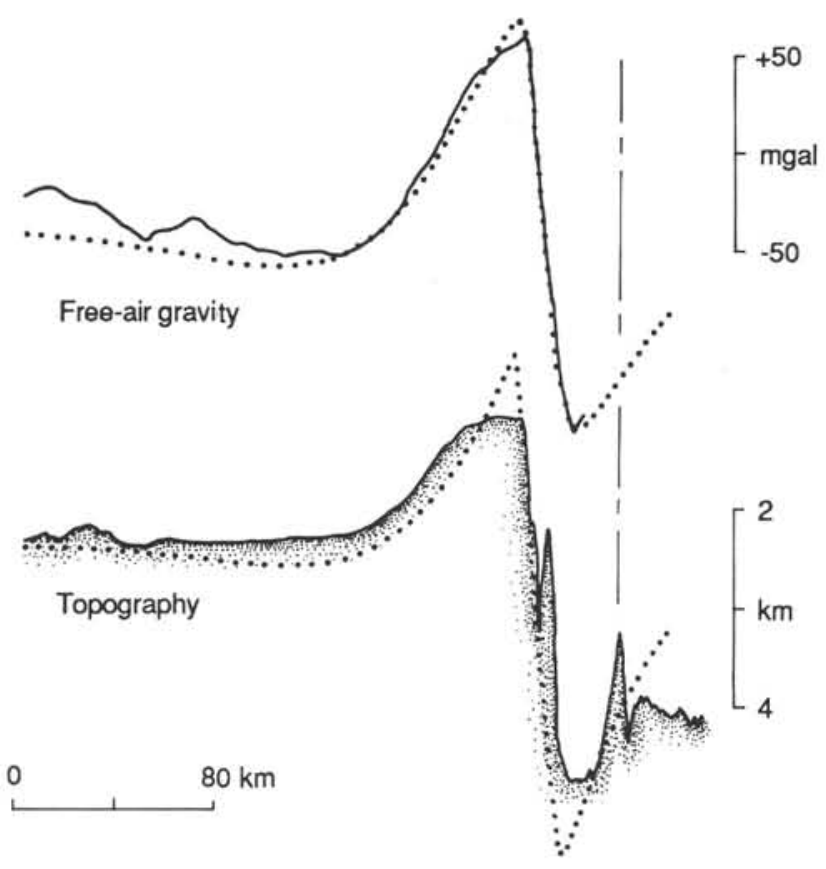

Figure 15. A. Calculated free-air gravity effect for the observed topography of Broken Ridge, assuming local isostasy and compensation via crustal thickening. The large discrepancy between the calculated and observed gravity anomaly ( $\sim 50$ mgal) strongly suggests that Broken Ridge is not supported by a crustal root or, alternatively, a negative density contrast. Consequently, a thermal support mechanism and/or magmatic underplating are inappropriate for Broken Ridge. B. Calculated free-air gravity effect based on the flexural uplift model of Weissel and Karner (in press). The successful prediction of both the free-air gravity and the general shape of the topography support a flexural origin for the uplift and the continued maintenance of Broken Ridge rift flank topography.

water depth and 20 -km-thick crust are isostatically balanced by a $60-\mathrm{km}$-thick lithosphere. This estimate of lithospheric thickness is consistent with the effective elastic thickness of the lithosphere used in modeling the free-air gravity anomaly across Broken Ridge.
The estimated subsidence rate on Broken Ridge prior to the middle Eocene is less than that expected for its pre-Turonian age, relative to the empirical subsidence curves of Parsons and Sclater (1977). In contrast, the observed post-rift ( $\sim 45-50 \mathrm{Ma})$ subsidence rates are significantly greater than that expected for 
thermally old ( $>90 \mathrm{Ma}$ ) lithosphere (Fig. 9). The low heatflow values at Broken Ridge are strong evidence against any reheating during rifting and, therefore, against a thermal "resetting" of subsidence rates. Alternative mechanisms must be invoked to explain the observed subsidence behavior of Broken Ridge.

First, we require a mechanism that diminishes the rate of subsidence of Broken Ridge prior to rifting. Broken Ridge was associated with a hot spot prior to the middle Eocene. Because lithospheric cooling rates are directly proportional to the temperature at the base of the lithosphere, the close proximity of the hot spot forces the base of the lithosphere (as defined by the $1300^{\circ}-1400^{\circ} \mathrm{C}$ isotherm $)$ to a shallower depth $(\sim 60 \mathrm{~km})$ than that for normal oceanic lithosphere $(\sim 125 \mathrm{~km})$. Consequently, while Broken Ridge remains in close proximity to the hot spot, its rate of subsidence will be less than that for normal oceanic lithosphere.

The aforementioned mechanism accounts for diminished rates of lithospheric subsidence prior to rifting. As a contrasting second step, we must account for accelerated rates of subsidence subsequent to rifting: (1) seafloor spreading moved Broken Ridge away from the proximity of the hot spot, thus allowing Broken Ridge lithosphere to thermally re-equilibrate to a normal lithospheric thickness $(\sim 125 \mathrm{~km})$, with a concurrent increase in subsidence rates, and (2) young oceanic lithosphere tends to subside faster than older lithosphere. Therefore, as the newly emplaced oceanic lithosphere adjacent to Broken Ridge subsides, mechanical coupling between Broken Ridge lithosphere and the southeast Indian Ridge lithosphere will accentuate the subsidence of the plateau while retarding the subsidence of the new lithosphere. However, both mechanisms should be operative, and further modeling is required to determine their relative importance.

\section{TECTONIC AND STRATIGRAPHIC MODEL FOR THE EVOLUTION OF BROKEN RIDGE}

A detailed study of the water gun seismic-reflection data, $3.5-\mathrm{kHz}$ PDR data, sonobuoy velocity data, and gravity anomaly data collected on RC2708, in conjunction with the ODP Leg 121 drilling results, reveals that the rifting process at Broken Ridge profoundly affected the preserved stratigraphy. We have developed the following tectonic model for the evolution of Broken Ridge, based on these data sources (Fig. 16).

1. Broken Ridge/Kerguelen-Heard Plateau was a shallowwater platform prior to the Turonian (see "Biostratigraphy" section, "Site 755" chapter) that formed as a consequence of excessive volcanism (hot spot) at or near a spreading center (Morgan, 1981). The plateau slowly subsided through much of the Late Cretaceous. Upper Turonian to lower Coniacian glauconite-rich sediments, up to coarse sand size, recovered at Site 755 may indicate a shallow-water environment. Organic geochemistry results indicate that small fractions of terrigenous plant material occur within the Turonian to Santonian tuffs (see the discussion of organic geochemistry in the "Geochemistry" section of the "Broken Ridge Summary" chapter).

Results from Site 748 , on the southwestern Kerguelen Plateau, indicate that the plateau was subaerially exposed or at very shallow depths and that the sediments consist of glauconitic sands and silts of Cenomanian, Turonian, and possibly Santonian age (Leg 120 Shipboard Scientific Party, 1988). These lines of evidence may suggest that the southern parts of the Broken Ridge/Kerguelen-Heard Plateau were emergent and vegetated. The central plateau (analogous to a wide ramp) experienced sediment transport to the north (toward Broken Ridge) that bypassed the high-energy shallow-water platform region, with subsequent sediment deposition occurring below the high-energy zone. The glauconite-rich zones recovered on Broken Ridge at Site 755 might indicate a lower relative sea-level stand and/or
$\mathrm{N}$

(1)

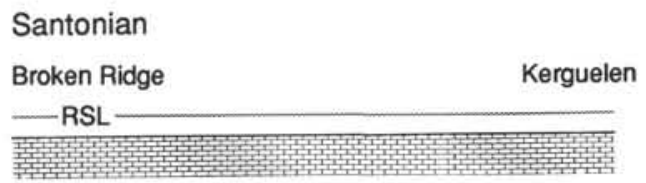

(2)

\section{Maestrichtian}

Broken Ridge

Kerguelen

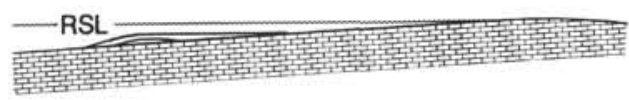

(3)

middle Eocene

$\infty$ Broken Ridge Kerguelen $\Rightarrow$

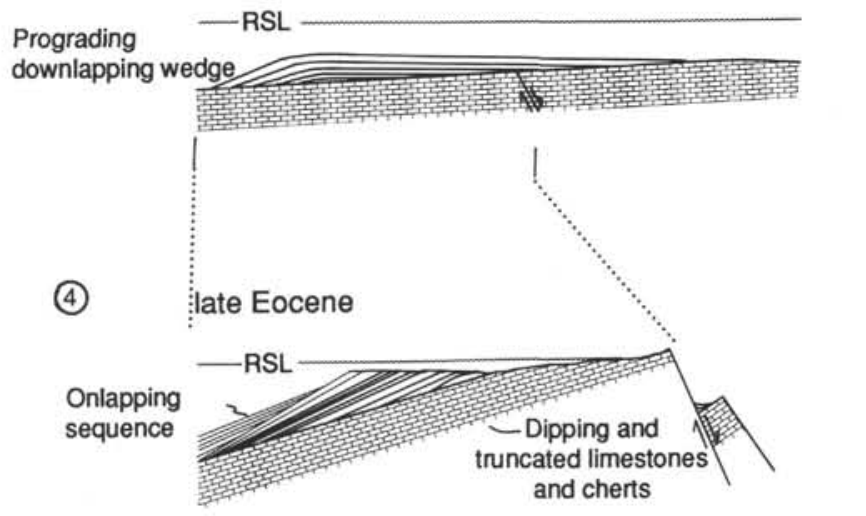

(5)

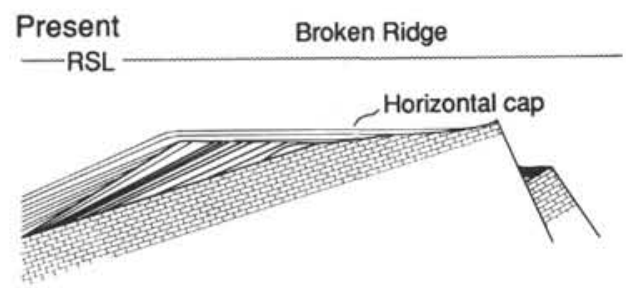

Figure 16. Tectonic and stratigraphic model illustrating the effects of a middle Eocene rifting event on the evolution of Broken Ridge from the Santonian to the present. RSL $=$ relative sea level.

episodes of greater current activity that would extend the zone of sediment bypass into deeper water (i.e., farther north).

2. Extensional horst and graben features on the southern Kerguelen-Heard Plateau were first identified by Houtz et al. (1977). The horst and graben province on the southern Kerguelen-Heard Plateau has been interpreted as an early stage, or a failed segment, of spreading during the breakup between the Kerguelen-Heard Plateau and Broken Ridge because of the central graben configuration superposed on a longer wavelength bathymetric high (Rotstein et al., in press). The associated unconformity resulting from the uplift of the southern KerguelenHeard Plateau has been dated as early Maestrichtian $(\sim 75 \mathrm{Ma})$ and was recorded at ODP Sites 747, 748, and (possibly) 750 as a hiatus (Leg 120 Shipboard Scientific Party, 1988). Analysis of the surrounding seismic stratigraphy on the southern KerguelenHeard Plateau indicates that the depocenter shifted sharply toward the northeast during the Maestrichtian uplift event (Leg 120 Shipboard Scientific Party, 1988). 
A dramatic increase in the calcium carbonate flux rate at Broken Ridge occurred between the early Santonian and the early Maestrichtian ( 86 and $76 \mathrm{Ma}$ ). The increase in carbonate flux is roughly coincident with the opening of the southeast Indian Ocean and may mark the initiation of open-ocean circulation. The carbonate flux rates $\left(\sim 6 \mathrm{~g} / \mathrm{cm}^{2} / 1000 \mathrm{yr}\right)$ are extremely high for mid-ocean conditions and are high even for high-productivity zones (see "Broken Ridge Summary" chapter). The uplifted parts of the southeastern Kerguelen-Heard Plateau could have further increased the observed Broken Ridge carbonate flux rates by increasing the nutrient supply through enhanced upwelling of nutrient-rich waters. Another possible cause of the high flux rates is sediment transport bypassing the high-energy shallow-water platform, with preferential deposition at greater water depths along the northern edge of the paleoplatform. The results of ODP Leg 121 drilling indicate that the prograding downlapping unit consists mostly of biogenic carbonate. Thus, the observed stratal relationships result from carbonate deposition on a gently dipping $\operatorname{ramp}\left(\ll 1^{\circ}\right)$.

High ash flux rates persisted from the Turonian through the early Eocene on Broken Ridge ( $~ 30$ m.y. duration; see "Broken Ridge Summary" chapter). The ash flux rate rapidly diminished with time. The variability of ash abundance within the carbonate, and the frequency of interbedded ash layers, appears to give rise to some of the different acoustic units observed within the prograding downlapping sequence (Fig. 4A).

3. Subsidence of the uplifted parts of the southeastern Kerguelen-Heard Plateau increased the submerged areas available for productivity. The phase lag between the time of marine incursion and the resulting increase in biogenic productivity should be short, because the carbonate-producing algae are suspended in the water column. The biogenic sediment would prograde farther northward as a result of the increase in the productivity. Mullins et al. (1988) observed a similar phenomenon on the western Florida escarpment, where middle Miocene clinoforms prograded basinward during a long-term relative sea-level rise.

4. Rifting of the Broken Ridge/Kerguelen-Heard Plateau began approximately in the middle Eocene (43-45 Ma), based on ODP Leg 121 drilling results. Flexural modeling of the rift flank topography assumed that rifting between Broken Ridge and Kerguelen-Heard Plateau occurred along a southward-dipping detachment (Weissel and Karner, in press). The approximately $2000 \mathrm{~m}$ of uplift predicted by this modeling suggests that about $1000 \mathrm{~m}$ of material was eroded from the summit of Broken Ridge. The eroded material onlaps the prograding downlapping sequence at the base of the pre-existing slope and progressively onlaps up the northern slope of Broken Ridge (Figs. 3B and 4A). Onlapping sequence I ponds in the structural lows at the base of the slope (Fig. 11A) and represents the beginning of post-rift deposition on Broken Ridge.

5. Continued thermal subsidence of the Broken Ridge region subsequent to rifting increased the accommodation zone which allowed the accumulation of the horizontal pelagic cap that onlaps the older dipping and truncated strata (Fig. 4A; Haq et al., 1987; Posamentier et al., 1989). The Oligocene hiatus observed within the Neogene cap is roughly coincident with a well-documented eustatic sea-level fall during the Oligocene ( $\sim 30 \mathrm{Ma}$; Haq et al., 1987). However, it is also coincident with the initiation of the ACC (Kennett, 1979). Clearly, further research is needed to discriminate between these two alternative explanations for the middle Oligocene hiatus. The sediments of the horizontal cap show signs of winnowing by the ACC (Kennett, 1979), and this winnowing might explain the observed thinning of the cap toward the northern edge of the ridge (Figs. 3B and $4 \mathrm{~A}$ ).

\section{CONCLUSIONS}

The free-air gravity anomaly observed over the Broken Ridge study area suggests that the topography is basically uncompensated in the sense that the Moho topography parallels the bathymetry. This is evidence for a lithosphere with finite flexural strength. Finite lithospheric strength during rifting can account for the tectonic uplift of Broken Ridge (the footwall block) owing to flexural rebound following removal of the hanging-wall block to the south (Kerguelen-Heard Plateau). This rift-induced uplift in the middle Eocene gently tilted the pre-existing strata toward the north and exposed parts of Broken Ridge to erosion. The resulting erosion led to the development of a major angular unconformity on Broken Ridge. The seismic-reflection data and the ODP Leg 121 drilling results indicate that the stratigraphic significance of the prominent angular unconformity on Broken Ridge is that it separates dipping and truncated Turonian to middle Eocene pre-rift sediments from horizontal late Eocene to Pleistocene post-rift sediments.

Stratigraphic sequence analysis and Leg 121 drilling data indicate that the stratal relationships developed between the dipping and truncated limestone, chalk, tuff, and chert sequence and the overlying prograding downlapping sequence resulted from high biogenic productivity in a broad, dipping carbonate ramp environment. Subsidence of the subaerially exposed parts of the ramp (i.e., the southeastern Kerguelen-Heard Plateau) increased the area available for biogenic productivity. The carbonate sediment prograded farther northward in response to this increased productivity. Subsequently, rapid uplift associated with the middle Eocene rifting event led to the erosion of Broken Ridge. The eroded carbonate material onlaps the prograding downlapping sequence at the base of the pre-existing slope. The deposition of this unit, onlapping sequence $\mathrm{I}$, was probably very rapid, which may account for the prevalent slump scars observed within it. The resulting debris/turbidity flows coalesced in the paleostructure lows and onlap sequence I. Continued thermal subsidence of the Broken Ridge region after rifting has allowed the accumulation of carbonate oozes above the truncation surface.

\section{REFERENCES}

Barton, P., and Wood, R. A., 1984. Tectonic evolution of the North Sea Basin: crustal stretching and subsidence. Geophys. J. R. Astron. Soc., 79:987-1022.

Coleman, P. J., Michael, P. J., and Mutter, J. C., 1982. The origin of Naturaliste Plateau, SE Indian Ocean: implications from dredged basalts. Aust. J. Earth Sci., 29:457-468.

Davies, T. A., Luyendyk, B. P., et al., 1974. Init. Repts. DSDP, 26: Washington (U.S. Govt. Printing Office).

Francis, T.J.G., and Raitt, R. W., 1967. Seismic refraction measurements in the southern Indian Ocean. J. Geophys. Res., 72:30153041 .

Haq, B. U., Hardenbol, J., and Vail, P. R., 1987. Chronology of fluctuating sea levels since the Triassic. Science, 235:1156-1167.

Houtz, R. E., Hayes, D. E., and Markl, R. G., 1977. Kerguelen Plateau bathymetry, sediment distribution and crustal structure. Mar. Geol., 25:95-130.

Karner, G. D., and Watts, A. B., 1982. On isostasy at Atlantic-type continental margins. J. Geophys. Res., 87:2923-2948.

Kennett, J. P., 1979. Cenozoic evolution of Antarctic glaciation, the Circum-Antarctic Ocean, and their impact on global paleoceanography. J. Geophys. Res., 82:3843-3860.

Kennett, J. P., and Burns, R. E., 1972. Australian-Antarctic continental drift, paleocirculation changes and Oligocene deep erosion. Nature, 239:51-55.

Leclaire, L., et al., 1987. Lower Cretaceous basalt and sediments from the Kerguelen Plateau. Geo. Mar. Lett., 7:169-176. 
Leg 120 Shipboard Scientific Party, 1988. That sinking feeling. Nature, 334:385-386.

Mahoney, J. J., MacDougall, J. D., Lugmair, G. W., and Gopalan, K., 1983. Kerguelen hot-spot source for Rajmahal traps and Ninetyeast Ridge? Nature, 303:385-389.

Markl, R. G., 1974. Evidence for the breakup of eastern Gondwanaland by the Early Cretaceous. Nature, 251:196-200.

Morgan, W. J., 1981. Hot spot tracks and the opening of the Atlantic and Indian Oceans. In Emiliani, C. (Ed.), The Sea: The Oceanic Lithosphere (vol. 7): New York (Wiley), 443-487.

Mullins, H. T., Gradulski, A. F., Hine, A. C., Melillo, A. J., Wise, S. W., Jr., and Applegate, J., 1988. Three-dimensional sedimentary framework of the carbonate ramp slope of central west Florida: a sequential seismic stratigraphic perspective. Geol. Soc. Am. Bull., 100: 514-533.

Munschy, M., and Schlich, R., 1987. Structure and evolution of the Kerguelen-Heard Plateau (Indian Ocean) deduced from seismic stratigraphy studies. Mar. Geol., 76:131-152.

Mutter, J. C., and Cande, S. C., 1983. The early opening between Broken Ridge and Kerguelen Plateau. Earth Planet. Sci. Lett., 65:369376.

Mutter, J. C., Hegarty, K. A., Cande, S. C., and Weissel, J. K., 1985. Breakup between Australia and Antarctica: a brief review in the light of new data. Tectonophysics, 114:255-279.

Parker, R. L., 1973. The rapid calculation of potential anomalies. Geophys. J. R. Astron. Soc., 31:447-455.

Parker, R. L., and Oldenburgh, D. W., 1973. A thermal model of oceanic ridges. Nature, 242:137-139.

Parsons, B., and Sclater, J. G., 1977. An analysis of the variation of ocean floor heat flow and bathymetry with age. J. Geophys. Res., 82:803-827.

Pitman, W. C., 1978. Relationships between eustacy and straigraphic sequences of passive margins. Geol. Soc. Am. Bull., 89:1389-1403.

Posamentier, H. W., Jervey, M. T., and Vail, P. R., 1989. Eustatic controls on clastic deposition. I. Conceptual framework. In Wilgus, C.,
Hastings, B. S., Posamentier, H., Van Wagonner, J., Ross, C. A., and Kendall, C. G. St. C. (Eds.), Sea Level Changes, An Integrated Approach: Spec. Publ. Soc. Econ. Paleontol. Mineral., 42:109-124.

Quilty, P. G., 1973. Cenomanian-Turonian and Neogene sediments from northeast of Kerguelen Ridge, Indian Ocean. Aust. J. Earth Sci., 20: 361-267.

Rotstein, Y., Schlich, R., and Munschy, M., in press. An extinct spreading center in the southern Kerguelen Plateau. Nature.

Talwani, M., Worzel, J. L., and Landisman, M., 1959. Rapid gravity computations for two-dimensional bodies with application to the Mendocino submarine fracture zone. J. Geophys. Res., 64:49-59.

Vail, P. R., 1987. Seismic stratigraphy interpretation utilizing sequence stratigraphy. In Bally, A. W. (Ed.), Atlas of Seismic Stratigraphy: AAPG Stud. Geol., 27:1-11.

Vail, P. R., Hardenbol, J., and Todd, R. G., 1984. Jurassic unconformities, chronostratigraphy and global sea-level changes from seismic stratigraphy and biostratigraphy. In Schlee, J. S. (Ed.), Interregional Unconformities and Hydrocarbon Accumulation: AAPG Memoir, 36:129-144.

Vail, P. R., Mitchum, R. M., Jr., Shipley, T. H., and Buffler, R. T., 1980. Unconformities of the North Atlantic. Philos. Trans. R. Soc. London, A, 294:137-155.

Vail, P. R., Mitchum, R. M., Jr., Todd, R. G., Widmier, J. M., Thompson, S., III, Sangree, J. B., Bubb, J. N., and Hatelid, W. G., 1977. Seismic stratigraphy and global changes of sea level. In Clayton, C. E. (Ed.), Seismic Stratigraphy: Application to Hydrocarbon Exploration: AAPG Memoir, 26:49-212.

Watts, A. B., Bodine, J. H., and Steckler, M. S., 1980. Observations of flexure and the state of stress in the oceanic lithosphere. J. Geophys. Res., 85:6369-6376.

Weissel, J. K., and Karner, G. D., in press. Flexural uplift of rift flanks due to mechanical unloading of the lithosphere during extension. $J$. Geophys. Res.

Ms 121A-104 